Review

\title{
Amyloids: The History of Toxicity and Functionality
}

\author{
Elmira I. Yakupova ${ }^{1,2, *}$, Liya G. Bobyleva ${ }^{1}$, Sergey A. Shumeyko ${ }^{1}$, Ivan M. Vikhlyantsev ${ }^{1}$ (1) \\ and Alexander G. Bobylev ${ }^{1}$ (i) \\ 1 Institute of Theoretical and Experimental Biophysics, Russian Academy of Sciences, Pushchino, \\ 142290 Moscow, Russia; liamar@rambler.ru (L.G.B.); shumik92@gmail.com (S.A.S.); \\ ivanvikhlyantsev@gmail.com (I.M.V.); bobylev1982@gmail.com (A.G.B.) \\ 2 A. N. Belozersky Institute of Physico-Chemical Biology, Lomonosov Moscow State University, \\ 119991 Moscow, Russia \\ * Correspondence: yakupova.mira@mail.ru; Tel.: +7-(985)687-77-27
}

Citation: Yakupova, E.I.; Bobyleva, L.G.; Shumeyko, S.A.; Vikhlyantsev, I.M.; Bobylev, A.G. Amyloids: The History of Toxicity and Functionality. Biology 2021, 10, 394. https://doi. org/10.3390/biology10050394

Academic Editor: Katsuya Iuchi

Received: 6 April 2021

Accepted: 29 April 2021

Published: 1 May 2021

Publisher's Note: MDPI stays neutral with regard to jurisdictional claims in published maps and institutional affiliations.

Copyright: (c) 2021 by the authors. Licensee MDPI, Basel, Switzerland. This article is an open access article distributed under the terms and conditions of the Creative Commons Attribution (CC BY) license (https:// creativecommons.org/licenses/by/ $4.0 /)$.
Simple Summary: This review presents the beginning of the history of toxic properties of amyloids, especially on $\mathrm{A} \beta$ amyloids. We discuss anti-amyloid therapy and its problems and write about new views on amyloids that can play positive roles in different organisms including human.

\begin{abstract}
Proteins can perform their specific function due to their molecular structure. Partial or complete unfolding of the polypeptide chain may lead to the misfolding and aggregation of proteins in turn, resulting in the formation of different structures such as amyloid aggregates. Amyloids are rigid protein aggregates with the cross- $\beta$ structure, resistant to most solvents and proteases. Because of their resistance to proteolysis, amyloid aggregates formed in the organism accumulate in tissues, promoting the development of various diseases called amyloidosis, for instance Alzheimer's diseases (AD). According to the main hypothesis, it is considered that the cause of AD is the formation and accumulation of amyloid plaques of $A \beta$. That is why $A \beta$-amyloid is the most studied representative of amyloids. Therefore, in this review, special attention is paid to the history of $A \beta$-amyloid toxicity. We note the main problems with anti-amyloid therapy and write about new views on amyloids that can play positive roles in the different organisms including humans.
\end{abstract}

Keywords: protein aggregation; amyloids; functional amyloids; amyloidosis; amyloidogenesis; Alzheimer's disease

\section{Introduction}

The history of the study of amyloidosis dates back to the 17th century, when a woman was found to have a greatly enlarged spleen, which was crudely cut out with a knife [1]. In later works of the 19th century, the term "wax liver" was used for an organ in which large quantities of an unknown substance had collected [2]. This is the point from which researchers started studying amyloids deposited in different organs of the body, affecting the liver, spleen, kidneys and so forth [2,3]. Such diseases have subsequently been named "amyloidosis".

Amyloids are defined as aggregates of misfolded peptides or proteins, with a quaternary cross- $\beta$ structure, due to which they possess properties such as insolubility and resistance to proteolysis [4]. Because of these properties, accumulation/deposition of amyloids may occur in the body, thereby resulting in considerable changes in the metabolism of tissues and organs [4]. Amyloids are believed to lead to the development of amyloidoses. Amyloidoses are a group of incurable diseases. More than 30 different amyloidogenic proteins are currently associated with various diseases in humans $[1,4]$. Some of these are well known, for example AD. It is not only amyloids that are found in specific deposits in tissues with amyloidosis. Proteins such as glycosaminoglycans, apolipoprotein E and serum amyloid P components are also often present [4]. 
Due to the research carried out by Prusiner and his colleagues in the 1980s, the nature of infectious diseases such as Creutzfeldt-Jakob disease in humans, scrapie in sheep and bovine spongiform encephalopathy became better known $[5,6]$. It turns out that these diseases are caused by proteins called prions (or rather their altered form). Prions are a unique class of infectious agents. All of these diseases are related to the prion protein $(\operatorname{PrP})$, which can change its conformation from a non-infected form (PrPSc) to an infected one [7]. This form is similar to an amyloid cross- $\beta$ conformation. Therefore, we can say that another class of amyloid diseases (prion diseases) has emerged.

Since the beginning of the 21st century, our knowledge of amyloids has advanced, thanks to data on protein aggregates with an amyloid structure that do not cause disease and may even have a specific role in the body. These are therefore called functional amyloids. Functional amyloids have been found in plants [8,9], prokaryotes [10-12] and eukaryotes [13-19], including mammals [16-18] and even humans [17,18]. All groups of organisms have adaptations that protect them from the toxic effects of amyloids. Here, we present a new perspective on amyloids that can play a positive role in different organisms.

\section{Toxic Properties of Amyloids (the Beginning of Their History)}

In the literature, amyloids are presented as being the main cause of development of diseases such as AD, amyloidosis of the liver and kidneys, etc. There is the main "cascade amyloid hypothesis" formulated by Hardy and Higgins (1992) [20]. According to this hypothesis, the cause of $\mathrm{AD}$ is formation and accumulation of amyloid plaques from fragments of the A $\beta$ amyloid precursor protein (APP), which cause a cascade of molecular events, leading to loss of cell function and their death [20]. It was initially shown that Down syndrome (trisomy 21) patients have an extra copy of the amyloid precursor gene on chromosome 21 . Their $A \beta$ levels are also high, and, by age 40 , they are likely to exhibit clinical symptoms of $\mathrm{AD}[21,22]$. The second discovery was the familial type of $\mathrm{AD}$, caused by mutations in the APP that lead to overproduction of $A \beta$ [23-27]. $A \beta$ is a 4.2-kDa short peptide of 40-42 amino acids, which is generated from intracellular cleavage of the APP by the sequential action of $\beta$-secretase and $\gamma$-secretase proteolytic enzymes [28].

In $\mathrm{AD}$, two types of aggregates are found: extracellular $\mathrm{A} \beta$ deposits and intracellular tau protein. The toxicity of intracellular aggregates seems to be due to the sequestration of crucial proteins, together with amyloid, which leads to loss of cellular function and even cell death [29]. In AD, intracellular tau aggregates can, in theory, trap functional proteins and tau itself, which might induce microtubule destabilization [29]. Hardy's hypothesis implies that, in $\mathrm{AD}$, accumulation of $\mathrm{A} \beta$-amyloids is the primary cause of neuronal death, and, for a post-mortem diagnosis, it is necessary to detect deposits of aggregated $A \beta$ [20]. This is why $A \beta$-amyloid is the most studied representative of amyloids. Therefore, in this review, special attention is paid to $A \beta$-amyloid.

$A \beta$ toxicity has been demonstrated on cultured nerve cells in vitro [29-32]. A study in 1989 showed that a peptide derived from the APP was toxic for hippocampal neurons in a culture [29]. Another study reported that a peptide ligand homologous to the first 28 residues of the $A \beta$-amyloid protein (A $\beta 1-28)$ increased the survival of cultured hippocampal neurons and appeared to have a neurotrophic effect [30]. In 1990, Whitson et al. detected that synthetic peptide $\beta 1-42$ has a neurite-promoting effect, including extensive dendritic branching and axonal elongation [33]. In addition to the neurotrophic effect, a neurotoxic effect of $A \beta$ has also been observed in other experiments [31]. For instance, in 1990, Yankner et al. showed that a portion of the amyloid beta protein, consisting of APP amino acids 25-35, contributed to trophic and, at the same time, toxic effects [31].

An article published in 1991 reported that the discovered in vitro effects could be caused by protein self-aggregation [32]. Data on the spontaneous assembly of a fulllength $\beta$-amyloid peptide ( $\beta 1-42)$ have already been reported in existing studies [33-35]. Based on this evidence, Pike et al. were perhaps the first researchers to assume that self-aggregation of $\beta 1-42$ determines whether peptide trophic or toxic properties will be found [32]. To verify the hypothesis, Pike et al. demonstrated that $\beta 1-42$ incubation 
influences the viability of hippocampal cultures in vitro. They found that pre-incubated $\beta 1-42$ caused a neurotoxic effect, while recently solubilized $\beta 1-42$ caused no toxicity but did promote neurite outgrowth [32]. Furthermore, toxicity of aggregates of the peptide that was incubated at $37^{\circ} \mathrm{C}$ for $24 \mathrm{~h}$ increased the cell death effect [32,33]. Strong neurotoxicity in certain peptide sequences in A $\beta 1-42$ (for example, $\beta 25-35$ ), which exhibited rapid aggregation, was detected immediately upon solubilization [30]. Thus, it was concluded that $A \beta$ toxicity is dependent on concentration, with low doses being protective and high doses being toxic [36]. A low dose of $A \beta$ may also protect cells from the effects of a subsequent high dose [36].

The next stage in the history of $A \beta$ toxicity included the hypothesis that negative effects on neurons are dependent on the ratio of $A \beta 1-42$ to $A \beta 1-40$ peptides. $A \beta 42: A \beta 40$ ratios of 3:7 ( 1 and $2 \mathrm{~h}$ ) and 10:0 ( 1 and $2 \mathrm{~h}$ ) were found to be associated with neurotoxicity in cultured mouse hippocampal neurons in vitro and to influence memory formation in mice in vivo. $A \beta 42: A \beta 40$ ratios of 1:9 and 0:10 did not show neurotoxicity at any stage of the aggregation process [37].

In many of the above studies, the toxic effect of $A \beta$ was observed. However, what is the mechanism of $\beta \mathrm{AP}$-mediated neurotoxicity? It is known that many aspects of calcium homeostasis change with aging (1987) [38] and that imbalances in calcium regulation lead to neural degeneration (1992) [39]. On this basis, in a 1993 study, it was suggested that one of the mechanisms behind the toxic effect of $A \beta$ is disturbance of $\mathrm{Ca}^{2+}$ homeostasis [40]. Mattson et al. [40] noted that an experimental increase in $\left[\mathrm{Ca}^{2+}\right]$ can induce antigenic and ultrastructural changes in neurons similar to those observed in neurofibrillary tangles in $\mathrm{AD}[32,41]$.

Continuing the research, Mattson concluded (in 1994) that A $\beta$ which arises from alternative processing of beta APP aggregation destabilizes $\mathrm{Ca}^{2+}$ homeostasis [42]. Furthermore, vulnerable neurons possess high levels of glutamate receptors [42], and several growth factors can stabilize $\mathrm{Ca}^{2+}$ and protect neurons against excitotoxic injury and $\mathrm{A} \beta$ toxicity [42]. In the same year (1994), Weiss et al., studying the neurotoxicity of $A \beta$ in primary murine cortical neurons, reported that $A \beta$ (fragment 25-35) led to neurodegeneration that is concentration-dependent, and this effect decreased in the presence of $\mathrm{Ca}^{2+}$ channel blockers such as nimodipine $(1-20 \mathrm{mM})$ and $\mathrm{Co}^{2+}(100 \mathrm{mM})$ [43]. In this context, neuronal $\mathrm{Ca}^{2+}$ homeostasis dysregulation is considered to be a common factor that underlies $\mathrm{AD}$ pathogenesis [44]. This effect is possible due to several mechanisms: direct interaction with membranes and further destabilization of the membrane structure [44-48]; formation of a cation-conducting pore [49-55]; and activation of cell surface receptors coupled with $\mathrm{Ca}^{2+}$ influx [56-58]. More recent studies also support the hypothesis of toxicity of $\mathrm{A} \beta$ amyloids, associated with changes in calcium homeostasis [59-65]. It is also assumed that neurotoxicity of $A \beta$ might occur via generation of reactive free radicals [65-72]. In 1992, the cytotoxic effects of $A \beta$ and an internal fragment encompassing residues 25-35 were shown using cultured cortical nerve cells. Vitamin $\mathrm{E}$ (known as an antioxidant and free radical scavenger) was found to inhibit $A \beta$-induced cell death [68]. At the same time (1992), five brain tissue sections from an AD case and five normal age-matched controls were studied with polyclonal antibodies against superoxide dismutase ( $\mathrm{CuZn}$ - and $\mathrm{Mn}$-forms) and catalase immunostaining [72]. As a result, a subgroup of neurofibrillary tangles (15-25\%) and senile plaques (50\%) showed immunoreactivity for both enzymes [72,73]. In 1994, Behl et al. suggested that $A \beta$ causes increased levels of $\mathrm{H}_{2} \mathrm{O}_{2}[74,75]$.

In 1994, research provided evidence that beta-amyloid can inactivate oxidationsensitive glutamine synthetase and creatine kinase enzymes [67]. A 1995 study investigated the release of nitric oxide (NO) from cultured rat microglia exposed to synthetic $A \beta 25-35$ and A $\beta 1-40$ (alone or in combination with cytokines IFN- $\alpha / \beta$, IL- $1 \beta$, TNF- $\alpha$ or TNF- $\beta$, including IFN- $\gamma$ ) [70]. Only IFN- $\gamma$ among the cytokines being tested induced release of NO from the cells. $\beta 25-35$ did not stimulate the release of nitric oxide by itself, but, in combination with IFN- $\gamma$, it caused NO release. In fact, $\beta 1-40$ triggered NO production in microglia by itself, and this effect increased in conjunction with IFN- $\gamma(100 \mathrm{U} / \mathrm{mL})$ [70]. 
In 2020, it was shown that docosahexaenoic acid can suppress oligomeric $A \beta$-induced reactive oxygen species [71].

Further evidence indicating that generalized oxidative stress is important in pathogenesis effects was provided by a study of hippocampal cells. The study demonstrated that tyrosine nitration is increased in neuronal cytoplasm as well as in the nuclei of both neurons and glia in the regions of $\mathrm{AD}$ pathology. Thus, there is strong evidence that peroxynitrite is involved in oxidative damage of AD pathology [68,69].

In 1997, using primary cultures of cerebellar granule cells and astrocytes, it was shown that nanomolar concentrations of peptides such as $A \beta-(1-40)$ and $A \beta-(25-35)$ potently activate transcription factor NF- $\mathrm{KB}$ [76]. The authors of this work also conducted an immunohistochemical analysis of brain slices from patients with AD. In this case, activation of NF- $\mathrm{kB}$ was also observed in neurons and astroglia. Activated NF- $\mathrm{kB}$ was observed near the plaques [76]. NF- $\kappa B$ activation can lead to neuroprotection [37] via inhibition of amyloid $\beta$-mediated neuronal apoptosis [37].

Apoptosis is known to play a role in many neurologic disorders, including AD [77-79]. Dickson noted some problems in earlier experiments on apoptosis in AD: (1) the data were observed on cell cultures in vitro, which cannot necessarily be extrapolated to organisms in vivo; (2) in cell culture research, very high concentrations of $A \beta$ are usually used, which do not exist in nature [80]; and (3) evidence for frank cellular apoptosis in AD is controversial [81].

$\mathrm{A} \beta$ is the main candidate for activation of apoptotic mechanisms in AD. It has recently been shown that insoluble $A \beta$ complexes, including protofibrils and oligomers, play a role in this process [82]. Findings indicate that $A \beta$ can activate caspases [83-92]. This mechanism can be triggered by the accumulation of $A \beta$ at the site of its synthesis in endoplasmic reticulum or endosomes, which causes activation of apoptotic mechanisms through the unfolded protein response or endoplasmic reticulum stress. Apoptosis may also occur if $A \beta$ activates alcohol dehydrogenase through mitochondrial stress [92].

The hypothesis of the toxic effects of APP protein fragments, having first undergone changes in favor of the toxic effects of $A \beta$ aggregates (fibrils), has now been revised in favor of the highest toxicity of oligomers. It has already been demonstrated that $A \beta$ oligomers exhibit neurotoxicity and cause neuronal damage [93-107]. A $\beta$ protofibrils prepared in in vitro conditions have a smaller diameter than amyloid fibrils and high $\beta$-sheet content. It has been shown that a genetic risk factor for AD (APOJ; encoding clusterin) promotes formation of oligomeric structures with soluble properties [94]. Such oligomeric assemblies are involved in cell death both in vitro and in vivo $[95,96]$. A study in which soluble A $\beta$ oligomeric species were extracted from the brain tissue of patients with AD showed that the presence of soluble oligomeric species correlates more closely with symptoms of the disease than with fibrils from amyloid plaques [97,98].

Mutations of the gene encoding APP are known to cause the development of AD [99]. It has been shown that two clinical mutations in the APP gene can increase the tendency of $A \beta$ to oligomerize $[100,101]$. Benilova et al. concluded that, at the time of their study (2012), further evidence was needed to support the oligomeric hypothesis [93]. Indeed, there are a number of difficulties associated with research into oligomeric forms of the peptides. Firstly, the solution contains a mixture of water-soluble A $\beta$ species [93]; and, secondly, as shown by Bitan et al., sodium dodecyl sulfate (SDS) can actually artificially induce oligomerization of $A \beta$ [102]. It is known that the SDS-PAGE method used for obtained monomers, trimers and tetramers (as major bands) [102] is not a reliable method. The presence of SDS therefore makes it difficult to extrapolate in vivo effects from in vitro evidence [93]. It is still necessary to show whether similar modifications of $A \beta$ monomers can occur in vivo. Some modifications of the peptide that can occur in vivo under the action of certain enzymes have already been discussed in the literature [104-106], but whether neurotoxicity in $\mathrm{AD}$ is associated with such modifications has not been fully elucidated.

The mechanisms behind the toxic effects of $A \beta$ oligomers on cells may also lead to disruption of calcium homeostasis, and this has yet to be discussed in the literature [107]. 
The effects of oligomers of $A \beta$ from both extracellular and intracellular $\mathrm{Ca}^{2+}$ sources have been shown [95,107]. The researchers also noted that $A \beta 42$ and its oligomers caused increased membrane permeability in general [107]. This can cause unregulated flux of ions and molecules and, in turn, may be a common mechanism of oligomer toxicity [107]. However, we should note that high oligomer concentrations were used for the experiment to increase $\mathrm{Ca}^{2+}$ signals (100-1000 times greater than the levels of soluble $\mathrm{A} \beta$ measured in the brain of AD patients [107]).

Oligomers can show toxicity through membrane, intracellular and receptor-mediated mechanisms $[78,108]$. A study has been conducted on A $\beta$ synaptotoxic effects, including disturbances in the functioning of $\mathrm{N}$-methyl d-aspartate (NMDA) receptors that can affect calcium influx $[79,108]$. However, whether A $\beta$ oligomers have a direct influence on NMDA receptors is a matter of controversy [97]. Alternative pathways suggest that $A \beta$ induces synaptic failure due to apoptotic pathway activation [109] or upregulation of nicotinic acetylcholine receptor $\alpha 7-n A c C h R 51$ [109]. There is evidence of interactions with the insulin receptor [110]. Furthermore, the effects on the hypoxia-induced factor, clustering of angiotensin type 2 receptor and other mechanisms have also been described [111,112]. Some studies have also measured induction of apoptosis or other markers of cell death [108]. It is also interesting that astrocyte cell cultures have been found to be resistant to the action of $A \beta$ [109]. Several reports in particular show that $A \beta$ deposits in the brain do not necessarily correlate with AD symptoms $[113,114]$. Thus, we can conclude that there is still no consensus on the main mechanism of the toxic effects of amyloid fibrils or/and $\mathrm{A} \beta$ oligomers.

\section{Anti-Amyloid Therapy and Its Problems}

Amyloidogenesis, amyloid aggregates found in $\mathrm{AD}$ and the disease itself have gained increasing attention in the search for therapeutic drugs. Therapeutic agents/molecules have various properties, including the ability to do the following [111]:

(1) Block $\beta$-sheet formation

(2) Prevent fibrillogenesis

(3) Dissolve $A \beta$ aggregates into non-toxic species

(4) Destabilize $A \beta$ oligomers

(5) Accelerate the conversion of $A \beta$ oligomers to $A \beta$ aggregates (modulators of $A \beta$ aggregation)

However, despite the fact that amyloids are considered to be the main cause of $\mathrm{AD}$ development, therapeutic agents designed to reduce $A \beta$-peptide production or prevent $A \beta$ peptide aggregation have been found to be ineffective in phase III clinical trials $[110,115]$. At the same time, the number of developments in the search for drugs to treat $\mathrm{AD}$ has already exceeded 2300 [115]. However, AD remains an incurable disease.

Recent comparative studies of amyloid aggregates formed in vitro and isolated from tissues indicate morphological differences in amyloids. In particular, brain-derived amyloid fibrils of $\mathrm{A} \beta$-peptides are right-twisted, while in vitro analogs are left-twisted [112]. This indicates that the study of amyloidogenesis in in vitro models has its own limitations, and the properties of "in vitro aggregates" may differ from their "in vivo analogs". Moreover, the study of amyloidogenesis in vivo is a very complex task, requiring development of new research methods. All this raises the critical question of whether it is correct to extrapolate results obtained from in vitro studies relating to amyloids to in vivo systems. At the same time, the hypothesis about the main role of amyloids in development of AD is not confirmed and does not come without criticism [111,116,117].

The above data once again cast doubt on the fact that amyloids are harmful to the body and do not play any positive role in cells. In this regard, it is necessary to highlight interesting data showing that amyloids in brain cells accumulate at a certain time of the day in all healthy people (picomolar concentrations) [118,119]. This is believed to have some positive effect [111]. In favor of this assumption, we include reference to the results of experiments demonstrating that, when drugs capable of reducing the formation of amyloids are used, neurons die. In one study, neuronal death was prevented by adding 
amyloids [120]. It has been shown that all known developed drugs with an anti-amyloid effect cause death in people [121,122]. For example, active A $\beta 1-42$ immunization (with AN-1792) resulted in $6 \%$ of patients developing meningoencephalitis [123]. At the same time, a reduction in senile plaques was observed [124], and none of these patients showed improved cognitive functioning [20]. Thus, should amyloids be treated as enemies or friends, and is it necessary to get rid of them?

To answer these questions, one of the strategies of anti-amyloid therapy, namely blocking the formation of $\beta$-sheets, should be discussed. This approach, in turn, depends on two membrane enzymes: $\beta$-secretase, also known as the $\beta$-site of the APP-cleaving enzyme (BACE1), and $\gamma$-secretase [23], consisting of five subunits, namely Pen-2, Presinilin 1 or Presinilin 2, Nicastrin and Aph1B. $\gamma$-secretase is involved in catalyzing the formation of several peptides, for instance, the Notch1 signal peptide, which plays a role in growth and proliferation of cellular processes [24]. It has been shown that subunit Presenilin 1 is important for the production of $A \beta$-peptide. One experiment found that knockout of the $\gamma$-secretase gene (in subunit Presenilin 1) caused the death of mice already at the embryonic stage [25]. Furthermore, inhibition of the entire $\gamma$-secretase gene by non-selective inhibitors led to various pathologies associated with Notch1 formation, including gastrointestinal tract disorders, impaired functioning of the immune system and skin pathologies $[25,26]$. In earlier studies, enzyme complex modulators instead of $\gamma$-secretase inhibitors were used to cause a shift in the production of $A \beta$-peptides from toxic $A \beta$ fragments (1-42) to less toxic and shorter ones [20]. Inhibition of $\beta$-secretase with knockout of the gene in mice led to interruption of the accumulation of $A \beta$-peptides $[21,27,28]$. Mice lacking $\beta$-secretase secretion reproduced relatively healthy offspring with minor phenotypic abnormalities, such as hypomyelination [29,30] and behavior with schizophrenia-like symptoms [30]. Some experiments have focused on the search for selective inhibitors of BACE1. It has been shown that inhibitor OM99-2 polypeptide is capable of penetrating the blood-brain barrier, and, in 2008, clinical studies of this polypeptide began [31]. This inhibitor has a limitation, i.e., a "bulky" peptide structure for in vivo conditions [31]. A drug was subsequently created on the basis of OM99-2, which was able to stay in the bloodstream for a longer time, pass through the blood-brain barrier and reduce the level of A $\beta$-peptides (30-65\%) in the plasma of transgenic mice modeling AD [32,39]. More than 10 drugs have been developed with similar characteristics. One of these has been found to be particularly successful (CTS-21166) and was tested on a group of volunteers suffering from Alzheimer's disease. These drugs are promising, but none of them have gone through all the stages of clinical research. Most of the tested compounds were withdrawn from the initial stages of clinical studies for various reasons. Thus, are amyloid deposits the main cause of $\mathrm{AD}$, and do their $A \beta$ toxic properties really cause the death of nerve cells?

Understanding the exact mechanism of toxicity caused by $\mathrm{A} \beta$ oligomers or aggregates/fibrils (or both) is still a matter of discussion. In 2012, Benilova et al. presented an interesting point of view, asserting that proof of this "invisible toxin" is comparable to the (in)famous teapot of the British philosopher Bertrand Russell [28]. Results from clinical tests on anti-amyloid drugs also suggest that the approach adopted in AD treatment needs to be reviewed. To do this, the multifactorial nature of this disease needs to be taken into account. While researchers pay full attention to amyloid deposits, they ignore the mechanisms of development of cytoskeleton abnormalities, inflammation, oxidative stress, other metabolic abnormalities, etc. (Figure 1) [21,125,126]. 


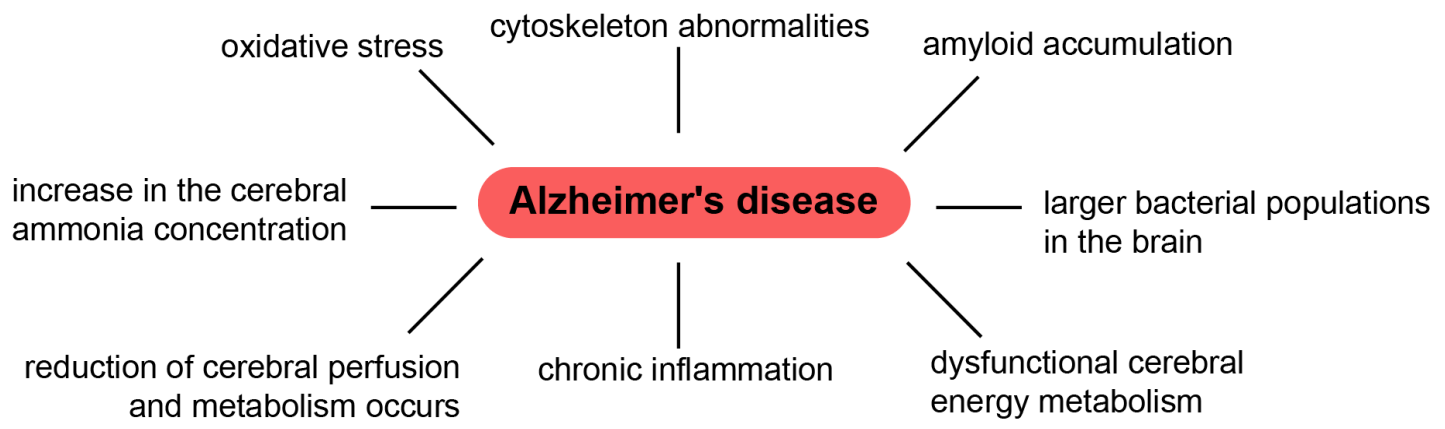

Figure 1. The mechanisms of AD.

We should not forget that the brain is extremely sensitive to fluctuations in blood glucose concentrations, and a lack of glucose for more than a few minutes can ultimately lead to cell death [127]. It is known that hypoglycemia [128], inadequate transportation of glucose across the blood-brain barrier [129], defective astroglial glutamate transport [130] and hyperammonemia [131] are associated with mental function. Comparison of the brains of patients who aged normally with the brains of $\mathrm{AD}$ patients has revealed certain metabolic differences, including glucose metabolism and cellular ATP, which decrease in the case of AD patients [132]. This supports the significant role of cerebral energy metabolism in AD pathology $[119,133-135]$. Thus, the cause of AD cannot only be due to amyloids but also other factors.

There is a hypothesis about the possible protective role of $\mathrm{A} \beta$ production in $\mathrm{AD}$ [136]. In the case of head trauma, neuroinflammation, ischemia-hypoxia/reperfusion, anesthesia or infectious agents, which are characteristically associated with neuronal damage [137,138], A $\beta$ may exhibit trophic and neuroprotective [30], antioxidant $[30,138]$ and antimicrobial properties [139]. A $\beta$ can also be observed in tissue after metabolic impairment by nonspecific stimuli [135].

Glucose and oxygen deregulation have been observed in patients with AD [126,140-142]. It has even been suggested that reduced mental capacity is caused by an imbalance of metabolic processes rather than the effects of $A \beta$ deposits [135]. Red blood cells in the brains of $\mathrm{AD}$ patients have poorer oxygen transport efficiency than those in patients with normal brains [143]. A study conducted by Kosenko et al. on metabolites and enzymes in the main metabolic pathways [135] reported an increase in red blood cell glycolysis and ion fluxes in $\operatorname{AD}[137,144]$.

With $A D$, reduced brain glucose availability results in an increase in the cerebral ammonia concentration $[145,146]$. Moreover, ammonia is a powerful neurotoxin, and its accumulation in $\mathrm{AD}$ brains might be the reason for deterioration of memory and cognitive abilities.

It should also be noted that there is chronic inflammation in the brains of AD patients, and several components are involved. Activation of the brain's resident macrophages (microglia) and specific cytokine signaling occurs in AD [147].

In 1992, immunohistochemical studies showed co-localization of the C1q component of the complement system, with amyloid deposits, in the brain of AD patients [148]. Researchers concluded that $A \beta$ amyloids can directly activate the complement system. After this, in vitro studies started to research direct activation by amyloid fibrils in the absence of antibodies, according to the classical pathway [148-155]. Such activation was also observed for the alternative pathway [156-158]. It has been demonstrated that complement activation by $A \beta$ fibrils in vitro results in the formation of $C 5 a$, as well as assembly of the C5b-9 proinflammatory membrane attack complex $[152,155]$. It has been shown that many complement system proteins, including C1q, C4, C3, C5, C6, C7, C8 and C5b-9, are also located near $A \beta$ deposits and neurofibrillary tangles in the brains of $A D$ patients $[150,152,158-162]$. This was followed by application of obtained data to new therapeutic approaches for reducing neuroinflammatory damage by influencing of the complement system response [161]. 
Recent in vitro studies do not confirm a direct antibody-independent complement system activated by $\mathrm{A} \beta$ fibrils [162]. However, the finding that complement system proteins are co-localized with amyloid deposit plaques needs to be explained further. It is worth noting that in addition to $\mathrm{A} \beta$ peptides, amyloid plaques contain other components, such as glycosaminoglycans, apopolyprotein E and amyloid serum component P [4]. Nevertheless, in this study [4], an association with the complement system was found only in the case of $A \beta$ peptides. This raises the question of which factor it activates. Increased bacterial populations in the brain of patients with $\mathrm{AD}$, compared with a normal brain, have been observed $[163,164]$. Therefore, Firmicutes, Actinobacteria and, in particular, P. acnes can directly play a role in neuroinflammation. In addition to co-localization of amyloids with the complement system, it has also been shown that amyloid aggregates have an antimicrobial function [164]. Thus, the complement system is more likely to be activated by microorganisms than by $A \beta$ fibrils or other components of amyloid inclusions [162]. However, microbiota can influence the development of neurodegenerative diseases through amyloid and lipopolysaccharide formation in the gut, which trigger an increased inflammation response in the brain $[165,166]$.

Thus, we can see that the primarily negative attention given to amyloids (especially $A \beta$ ) is changing now. There is no one uniform toxicity mechanism for $A \beta$ and other amyloids. We still do not know why or how proteins/peptides aggregate in vivo and the reason for this process. In this review, we pay close attention to the history of $A \beta$ toxicity in order to explain how researchers have studied amyloids and have come to a dead end, especially in AD treatment. Amyloids have still only been the subject of in vitro investigations. There are animal models of $\mathrm{AD}$, but they are still far removed from human pathology. We highlight the main problems with anti-amyloid therapy above and next consider a new perspective on amyloids that can play a positive role in the functioning of different organisms, including humans.

\section{Useful Properties of Amyloids. Functional Amyloids}

Evidence that amyloids may have positive properties has been reported, and we now know that amyloids have antioxidant $[137,138]$ and antibacterial effects $[4,139,164]$. Many amyloids are produced in the body, and it has been discovered that they play a vital role. Such amyloids are called functional amyloids. The first description of amyloidosis probably appeared in 1639 [1]. The first functional amyloid was discovered at the turn of the 20th century [10,167-169] (Figure 2). To date, more than 20 functional amyloids have been described.

Functional amyloids have various roles (Table 1), from formation of dense hydrophobic monolayers on the surface of spores and fruiting bodies of some fungi [166] to formation of the carcass of spider silk [15]; from protection of melanin toxic intermediates in melanosomes $[16,17]$ to formation of long-term memory in animals $[16,170]$. They are involved in the fertilization process in mice [17] and regulation of the synthesis (or content) of hormones in humans [19]. Recent data indicate that amyloid aggregates can participate in immune responses because they are part of the extracellular neutrophil trap [171]. Functional amyloids are found in muscle tissue. It has been shown that, during regeneration of skeletal muscles in mice and humans, the cytoplasmic RNA-binding protein TDP-43 forms amyloid-like oligomers called myogranules [172]. Amyloids have also an RNA-modulating ability and play a role in transcription, translation, storage and degradation of RNA [173]. It has been shown that some motifs in prions of fungi and humans can be functionally related and be a model of amyloid signaling mechanisms from fungi to mammals $[174,175]$. Prokaryotic cells can also use such properties [8]. Just as people can store hormones in amyloids, plants can also store their protein using amyloid formation [8]. 


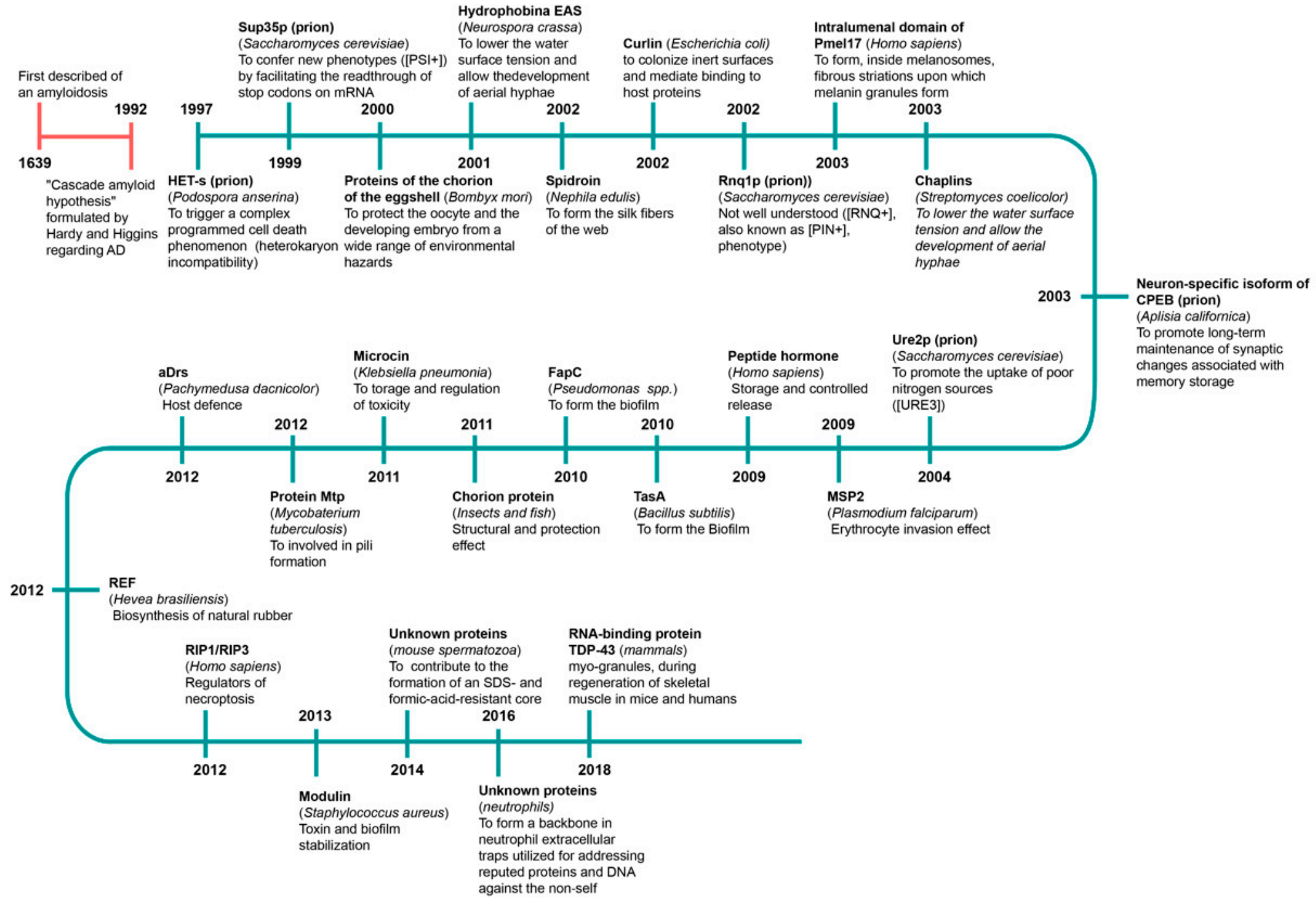

Figure 2. Timeline of history of functional amyloid discoveries. The name, host and function are presented. 
Table 1. The prevalence of functional amyloids and features of their research [176-228].

\begin{tabular}{|c|c|c|c|c|c|c|c|c|c|}
\hline $\begin{array}{l}\text { Species or } \\
\text { Organisms }\end{array}$ & $\begin{array}{l}\text { Protein or } \\
\text { Peptide }\end{array}$ & Function & Mol. Weight & Structure & $\begin{array}{c}\text { Evidence of } \\
\text { Cross } \\
\beta \text {-Structure } \\
\text { Presence }\end{array}$ & $\begin{array}{c}\text { Secondary Structure } \\
\text { Changes }\end{array}$ & $\begin{array}{l}\text { Congo } \\
\text { Red and } \\
\text { ThT } \\
\text { Binding }\end{array}$ & $\begin{array}{l}\text { Condition of in vitro } \\
\text { Amyloid Fibril } \\
\text { Forming }\end{array}$ & References \\
\hline \multicolumn{10}{|c|}{ Bacteria } \\
\hline $\begin{array}{l}\text { Escherichia coli, } \\
\text { Salmonella spp. }\end{array}$ & Curli & $\begin{array}{l}\text { Biofilm } \\
\text { formation, host } \\
\text { invasion. }\end{array}$ & $\begin{array}{l}\text { CsgA (main } \\
\text { damain of } \\
\text { curlin) } \\
\sim 17.5 \mathrm{kDa} .\end{array}$ & $\begin{array}{l}\text { Previously } \\
\beta \text {-structure. }\end{array}$ & $\begin{array}{l}\text { X-ray } \\
\text { diffraction for } \\
\text { CsgA. }\end{array}$ & $\begin{array}{c}\text { CD method: } \\
\text { CsgA fibrils are as } \\
\text { follows: } 16 \pm 2 \% \\
\alpha \text {-helix, } 40 \pm 2 \% \\
\beta \text {-sheet, } 13 \pm 2 \% \beta \text {-turn } \\
\text { and } 31 \pm 2 \% \text { remainder. }\end{array}$ & CR, ThT & $\begin{array}{c}\text { CsgA fibrils were } \\
\text { prepared by dialyzing } \\
\text { purified protein into } \\
25 \mathrm{mM} \text { Tris, } \mathrm{pH} 7.5, \\
100 \mathrm{mM} \mathrm{NaCl} \text { and } \\
0.5 \mathrm{mM} \text { EDTA and } \\
\text { incubating at room } \\
\text { temperature (RT) for } \\
\text { several days. }\end{array}$ & $\begin{array}{c}{[176,193-} \\
195]\end{array}$ \\
\hline $\begin{array}{c}\text { Streptomyces } \\
\text { coelicolor }\end{array}$ & Chaplins & $\begin{array}{c}\text { Modulation of } \\
\text { water surface } \\
\text { tension (i.e., } \\
\text { development of } \\
\text { aerial } \\
\text { structures). }\end{array}$ & $\begin{array}{l}\text { ChpD-H up to } \\
6 \mathrm{kDa} \\
\text { ChpA-C } \\
\sim 17-20 \mathrm{kDa} .\end{array}$ & $\begin{array}{l}\text { ChpD and ChpF } \\
\text { comprise } \beta \text {-sheet; } \\
\text { ChpE is random } \\
\text { coil (RC); ChpG } \\
\text { and ChpH have } \\
\text { mixed secondary } \\
\text { structure } \\
\text { comprising } \\
\text { elements of both } \\
\beta \text {-sheet and RC. }\end{array}$ & $\begin{array}{c}\text { X-ray } \\
\text { diffraction. }\end{array}$ & $\begin{array}{l}\text { CD method: } \\
\text { the protein mixture } \\
\text { adopted a conformation } \\
\text { rich in } \beta \text {-sheet. }\end{array}$ & ThT & $\begin{array}{l}\text { Synthetic chaplin } \\
\text { peptides were } \\
\text { dissolved at a final } \\
\text { concentration of } \\
0.5 \mathrm{mg} / \mathrm{mL} \text { in water } \\
\text { and the pH adjusted } \\
\text { by titration of } \\
\mathrm{NaOH} / \mathrm{HCl} \text {. }\end{array}$ & {$[11,196]$} \\
\hline $\begin{array}{c}\text { Rhizobium } \\
\text { leguminosarum }\end{array}$ & $\begin{array}{l}\text { RopA and } \\
\text { RopB }\end{array}$ & $\begin{array}{l}\text { Possibility role } \\
\text { in the control of } \\
\text { plant-microbial } \\
\text { symbiosis. }\end{array}$ & $\begin{array}{c}\text { RopA } 38.97 \\
\text { kDa } \\
\text { RopB } 22 \text { kDa. }\end{array}$ & $\begin{array}{l}\text { Previously } \beta \text { - } \\
\text { structure. }\end{array}$ & none & $\begin{array}{c}\text { CD method: } \\
\text { Before aggregation: } \\
\text { RopA more than } 40 \% \\
\beta \text {-structure, } \\
\text { RopB more than } 30 \% \\
\beta \text {-structure } \\
\text { After aggregation: } \\
42 \% \text { and } 38 \% \\
\beta \text {-structure for RopA } \\
\text { and RopB aggregates } \\
\text { respectively. }\end{array}$ & CR, ThT & $\begin{array}{c}\text { Proteins were } \\
\text { dissolved in } \\
\text { 1,1,1,3,3,3-hexafluoro- } \\
\text { 2-propanol (HFIP) } \\
\text { and incubated for } \\
\text { seven days. } \\
\text { Afterward, HFIP was } \\
\text { evaporated under a } \\
\text { stream of nitrogen, } \\
\text { and the samples were } \\
\text { stirred for an } \\
\text { additional } \\
\text { seven days. }\end{array}$ & [197] \\
\hline
\end{tabular}


Table 1. Cont.

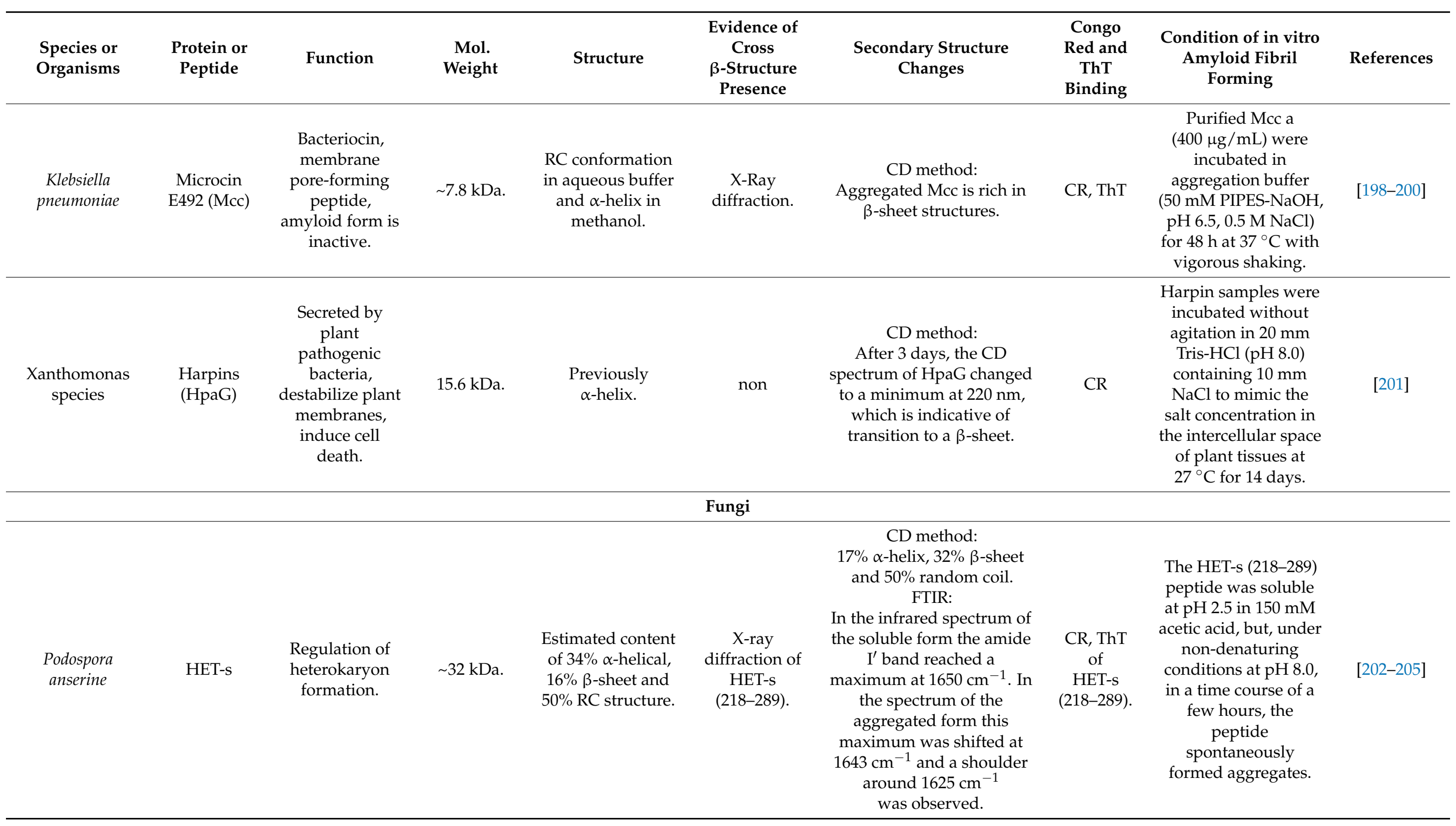


Table 1. Cont.

\begin{tabular}{|c|c|c|c|c|c|c|c|c|c|}
\hline $\begin{array}{l}\text { Species or } \\
\text { Organisms }\end{array}$ & $\begin{array}{l}\text { Protein or } \\
\text { Peptide }\end{array}$ & Function & Mol. Weight & Structure & $\begin{array}{l}\text { Evidence of } \\
\text { Cross } \\
\beta \text {-Structure } \\
\text { Presence }\end{array}$ & $\begin{array}{c}\text { Secondary Structure } \\
\text { Changes }\end{array}$ & $\begin{array}{l}\text { Congo } \\
\text { Red and } \\
\text { ThT } \\
\text { Binding }\end{array}$ & $\begin{array}{l}\text { Condition of in vitro } \\
\text { Amyloid Fibril } \\
\text { Forming }\end{array}$ & References \\
\hline \multirow[b]{2}{*}{$\begin{array}{l}\text { Saccharomyces } \\
\text { cerevisiae }\end{array}$} & URE2p & $\begin{array}{l}\text { Regulation of } \\
\text { nitrogen } \\
\text { catabolism. }\end{array}$ & $\sim 38 \mathrm{kDa}$ & $\begin{array}{l}\beta \text {-strands, } \alpha \text {-helix } \\
\text { and RC. }\end{array}$ & $\begin{array}{c}\text { Electron } \\
\text { diffraction, } \\
\text { X-ray } \\
\text { diffraction and } \\
\text { X-ray } \\
\text { diffraction } \\
\text { (PFD domain). }\end{array}$ & $\begin{array}{l}\text { CD method of PFD } \\
\text { domain: } \\
\text { Switching from an } \\
\text { initially disordered, RC } \\
\text { structure, to a } \beta \text {-sheet } \\
\text { enriched conformation. } \\
\text { FTIR of PFD domain: } \\
\text { A band at } ~ 1625 \mathrm{~cm}^{-1} \\
\text { dominates the spectrum } \\
\text { (the presence of } \\
\text { intermolecular } \\
\beta \text {-sheet structure). }\end{array}$ & CR, ThT & $\begin{array}{c}\text { Filaments were made } \\
\text { by incubation of } \\
\text { protein solutions } \\
\text { (usually at about } \\
1 \mathrm{mg} / \mathrm{mL} \text { ) on a } \\
\text { shaker for } 16 \mathrm{~h} \\
\text { at } 4^{\circ} \mathrm{C} \text {. }\end{array}$ & {$[206,207]$} \\
\hline & $\begin{array}{l}\text { Sup35p (Prion- } \\
\text { inducing } \\
\text { domain 2-114 } \\
\text { and PFD } \\
\text { domain) }\end{array}$ & $\begin{array}{l}\text { Regulation of } \\
\text { stop-codon } \\
\text { read-through. }\end{array}$ & 75 kDa. & $\begin{array}{c}\text { A freshly } \\
\text { prepared solution } \\
\text { exhibits a far UV } \\
\text { CD spectrum that } \\
\text { indicates little } \\
\alpha \text {-helix or } \beta \text {-sheet } \\
\text { content. }\end{array}$ & $\begin{array}{c}\text { X-ray } \\
\text { diffraction } \\
\text { (PFD domain). }\end{array}$ & $\begin{array}{c}\text { CD method } \\
\text { (PFD domain): } \\
\text { Switching from an } \\
\text { initially disordered, RC } \\
\text { structure, to a } \beta \text {-sheet } \\
\text { enriched conformation. } \\
\text { FTIR: } \\
\text { A band at } \sim 1625 \mathrm{~cm}^{-1} \\
\text { dominates } \\
\text { the spectrum. }\end{array}$ & CR & $\begin{array}{l}\text { Filaments of Sup35pN } \\
\text { (Prion-inducing } \\
\text { domain 2-114) were } \\
\text { prepared in } 0.1 \% \\
\text { (vol/vol) TFA } / 40 \% \\
\text { (vol/vol) acetonitrile } \\
\text { using reverse-phase } \\
\text { HPLC fractions } \\
\text { containing } \\
\text { isocratically eluted } \\
\text { Sup35pN. Preparation } \\
\text { of a } 100 \mu \text { M solution } \\
\text { of Sup35pN yielded } \\
\text { filaments after } 1 \text { week } \\
\text { of incubation at } 4{ }^{\circ} \mathrm{C} \text {. } \\
\text { Spontaneous filament } \\
\text { formation exists in } \\
50 \text { mM sodium } \\
\text { phosphate buffer } \\
\text { (pH 2.0) with } 40 \% \\
\text { acetonitrile. }\end{array}$ & [207-209] \\
\hline
\end{tabular}


Table 1. Cont.

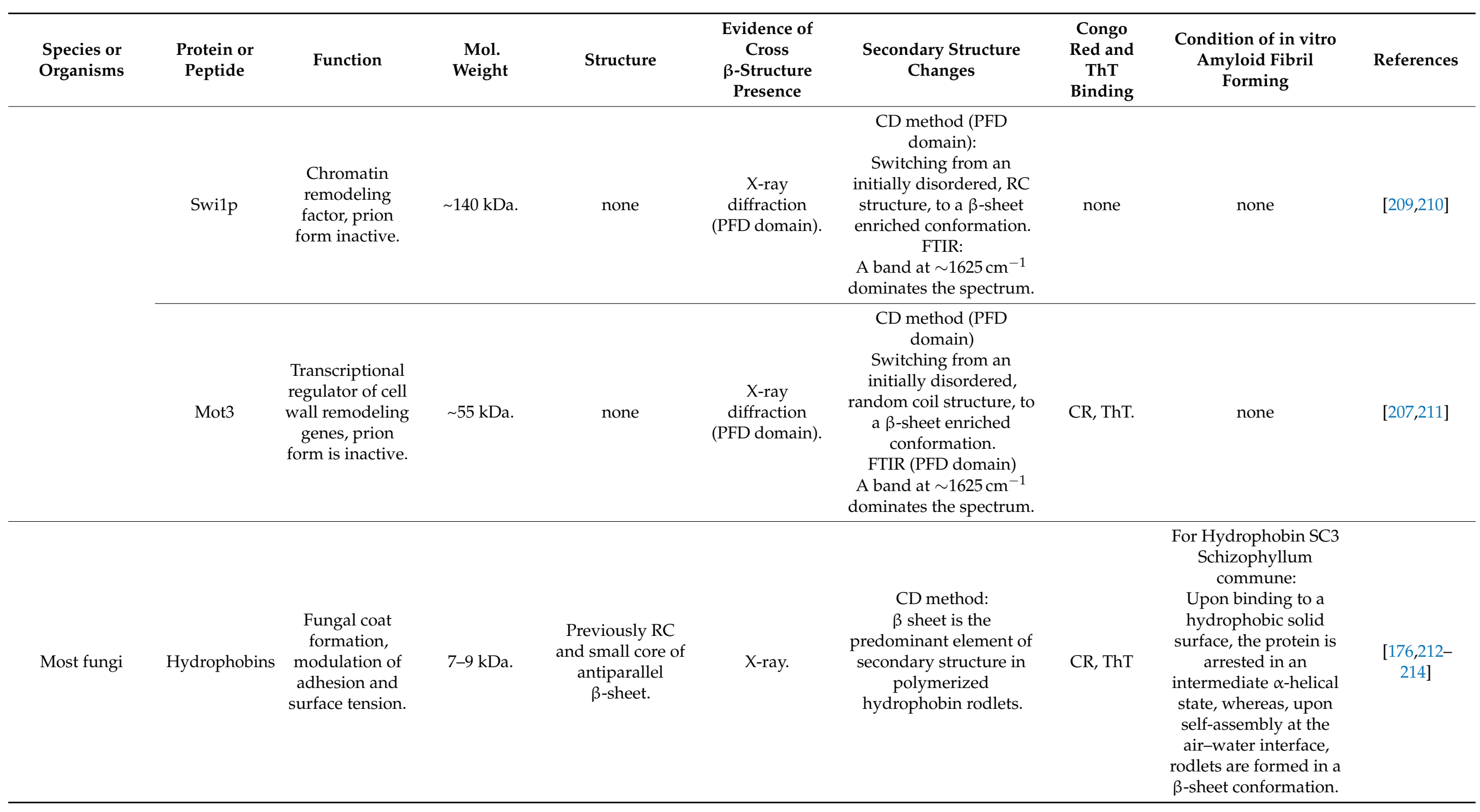


Table 1. Cont.

\begin{tabular}{|c|c|c|c|c|c|c|c|c|c|}
\hline $\begin{array}{l}\text { Species or } \\
\text { Organisms }\end{array}$ & $\begin{array}{l}\text { Protein or } \\
\text { Peptide }\end{array}$ & Function & Mol. Weight & Structure & $\begin{array}{c}\text { Evidence of } \\
\text { Cross } \\
\beta \text {-Structure } \\
\text { Presence }\end{array}$ & $\begin{array}{c}\text { Secondary Structure } \\
\text { Changes }\end{array}$ & $\begin{array}{l}\text { Congo } \\
\text { Red and } \\
\text { ThT } \\
\text { Binding }\end{array}$ & $\begin{array}{l}\text { Condition of in vitro } \\
\text { Amyloid Fibril } \\
\text { Forming }\end{array}$ & References \\
\hline \multicolumn{10}{|c|}{ Animal } \\
\hline Insects and fish & $\begin{array}{l}\text { Chorion } \\
\text { proteins } \\
\text { (central } \\
\text { domain of } \\
\text { silkmoth } \\
\text { chorion } \\
\text { proteins of the } \\
\text { A and B } \\
\text {-family) }\end{array}$ & $\begin{array}{l}\text { Structural and } \\
\text { protective } \\
\text { functions in the } \\
\text { eggshell. }\end{array}$ & 34 and $24 \mathrm{kDa}$. & $\begin{array}{c}\text { In both families of } \\
\text { proteins } \beta \text {-sheet } \\
\text { structure } \\
\text { predominates. }\end{array}$ & $\begin{array}{c}\text { X-ray } \\
\text { diffraction }\end{array}$ & $\begin{array}{c}\text { FTIR method } \\
\text { ATR FT-IR supports the } \\
\text { presence of uniform } \\
\beta \text {-sheets in the } \\
\text { structure of cA_m1 } \\
\text { peptide fibrils; } \\
\beta \text {-sheet structure also } \\
\text { suggested by X-ray } \\
\text { diffraction ATR FT-IR } \\
\text { data: } \\
64 \% \text { antiparallel } \beta \text {-sheet } \\
\text { and } 30 \% \beta \text {-turns in the } \\
\text { central domain of } \\
\text { silkmoth chorion } \\
\text { proteins. }\end{array}$ & CR & $\begin{array}{l}\text { cA peptide (central } \\
\text { domain of the A class } \\
\text { of silkmoth chorion } \\
\text { proteins) was } \\
\text { dissolved in a } 50 \mathrm{mM} \\
\text { sodium acetate buffer } \\
\text { (pH 5) at a } \\
\text { concentration of } 9 \\
\mathrm{mg} / \mathrm{mL} \text { to produce } \\
\text { amyloid-like fibrils } \\
\text { after 3-4 weeks } \\
\text { incubation. }\end{array}$ & {$[14,215-218]$} \\
\hline $\begin{array}{c}\text { Nephila clavipes } \\
\text { Nephila edulis } \\
\text { Araneus } \\
\text { diadematus }\end{array}$ & $\begin{array}{l}\text { Spidroins and } \\
\text { Araneus } \\
\text { diadematus } \\
\text { fibroin }\end{array}$ & $\begin{array}{l}\text { Structural (i.e., } \\
\text { spider silk). }\end{array}$ & $\begin{array}{l}\sim 320 \mathrm{kDa} \\
\text { (spidroin). }\end{array}$ & $\begin{array}{c}\beta \text {-sheet or } \beta \text {-turn } \\
\text { and RC. }\end{array}$ & $\begin{array}{c}\text { X-Ray } \\
\text { diffraction. }\end{array}$ & $\begin{array}{l}\text { CD method: } \\
\text { increasing of } \beta \text {-sheet } \\
\text { structures. }\end{array}$ & CR, ThT & $\begin{array}{c}\text { Lyophilized protein } \\
\text { was dissolved in } 6 \mathrm{M} \\
\text { guanidinium } \\
\text { thiocyanate at a } \\
\text { concentration of } 10 \\
\mathrm{mg} / \mathrm{mL}^{-1} \text { and } \\
\text { dialyzed against } 10 \times \\
10^{-3} \mathrm{M} \text { potassium } \\
\text { phosphate for several } \\
\text { days at RT. For } \\
\text { acceleration of fibril } \\
\text { formation, } 10 \text { vol.- } \% \\
\text { methanol was added. }\end{array}$ & {$[15,177,219]$} \\
\hline
\end{tabular}


Table 1. Cont.

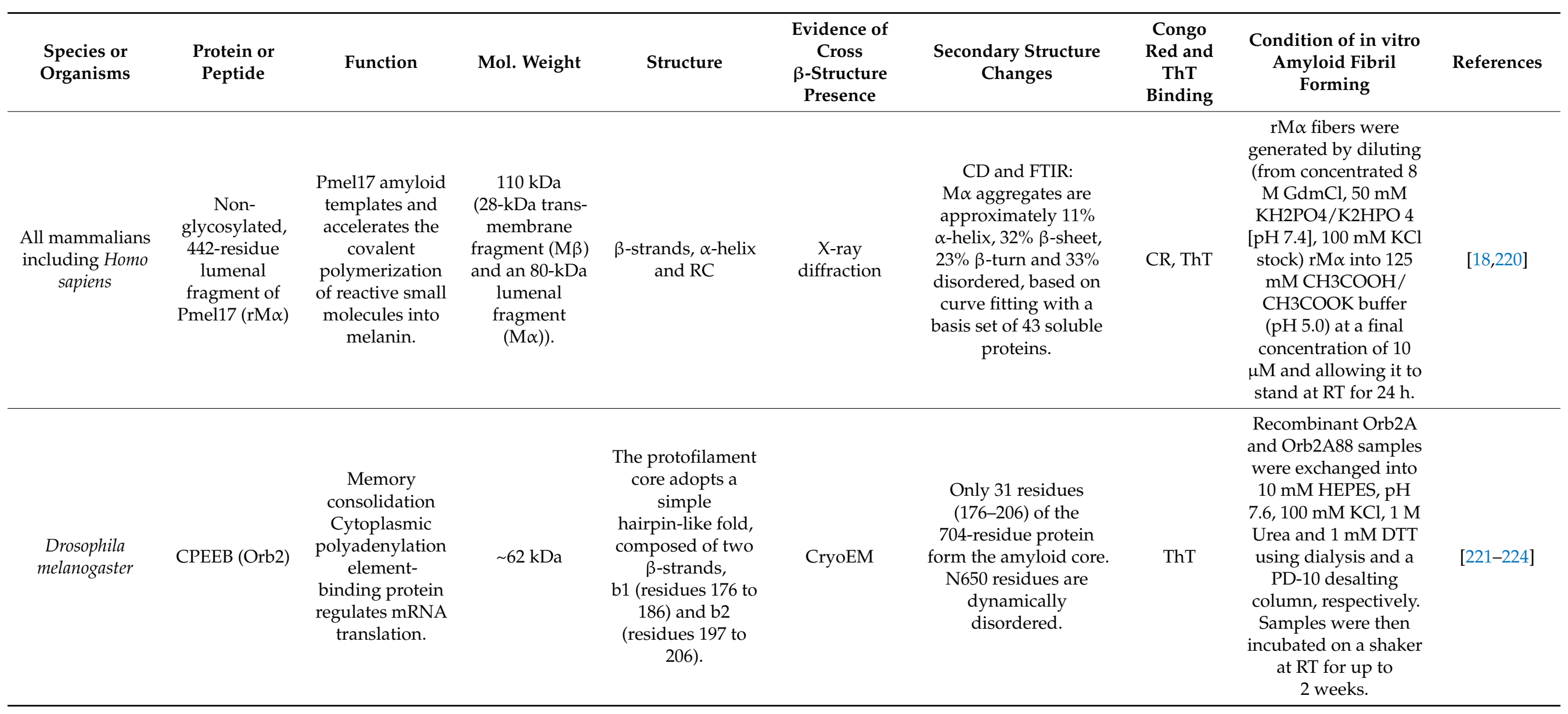


Table 1. Cont.

\begin{tabular}{|c|c|c|c|c|c|c|c|c|c|}
\hline $\begin{array}{l}\text { Species or } \\
\text { Organisms }\end{array}$ & $\begin{array}{l}\text { Protein or } \\
\text { Peptide }\end{array}$ & Function & Mol. Weight & Structure & $\begin{array}{l}\text { Evidence of } \\
\text { Cross } \\
\beta \text {-Structure } \\
\text { Presence }\end{array}$ & $\begin{array}{c}\text { Secondary Structure } \\
\text { Changes }\end{array}$ & $\begin{array}{l}\text { Congo } \\
\text { Red and } \\
\text { ThT } \\
\text { Binding }\end{array}$ & $\begin{array}{l}\text { Condition of in vitro } \\
\text { Amyloid Fibril } \\
\text { Forming }\end{array}$ & References \\
\hline \multicolumn{10}{|c|}{ Plants } \\
\hline Pisum sativum $\mathrm{L}$. & $\begin{array}{c}\text { Vicilin } \\
\text { (Cupin-1.1 } \\
((19-166 \text { aa }) \\
\text { and Cupin-1.2 } \\
(229-394 \text { aa }))\end{array}$ & $\begin{array}{c}\text { Amyloid } \\
\text { formation in } \\
\text { charge of the } \\
\text { accumulation of } \\
\text { storage proteins } \\
\text { in plant seeds. }\end{array}$ & $\sim 50$ kDa. & $\beta$-barrel domains. & $\begin{array}{c}\text { X-Ray } \\
\text { diffraction. }\end{array}$ & $\begin{array}{c}\text { CD method } \\
\text { Before aggregation } \\
\text { Cupin-1.1 and } \\
\text { Cupin-1.2 (4-12\% } \\
\beta \text {-content), Vicilin (39\% } \\
\beta \text {-content) } \\
\text { After aggregation } \\
\text { Cupin-1.1,Cupin-1.2 } \\
\text { and Vicilin (40-42\% } \\
\beta \text {-content). }\end{array}$ & CR, ThT. & $\begin{array}{c}\text { 1,1,1,3,3,3- } \\
\text { Hexafluoro-2- } \\
\text { propanol (HFIP) } \\
\text { solvent for the } \\
\text { proteins dissolution } \\
\text { with its subsequent } \\
\text { removal from the } \\
\text { sample and } \\
\text { incubation of } \\
\text { dissolved proteins in } \\
\text { the distilled water at } \\
37^{\circ} \mathrm{C} \text { for } 7 \text { days for } \\
\text { Vicilin, Cupin-1.1, } \\
\text { Cupin-1.2 and } 5 \mathrm{mM} \\
\text { phosphate buffered } \\
\text { saline (PBS) [pH } 7.4] \text { ) } \\
\text { for one day at } 25^{\circ} \mathrm{C} \text { ) } \\
\text { for Cupin-1.2 }\end{array}$ & [8] \\
\hline \multicolumn{10}{|c|}{ Synthetic amyloid aggregates } \\
\hline $\begin{array}{l}\text { Synthesized } \\
\text { peptides (Homo } \\
\text { sapiens and } \\
\text { Mouse) }\end{array}$ & $\begin{array}{c}\text { Vascin } \\
\text { (Peptide based } \\
\text { on an amy- } \\
\text { loidogenic } \\
\text { sequence in } \\
\text { the vascular } \\
\text { endothelial } \\
\text { growth factor } \\
\text { receptor } \\
\text { (VEGFR2) }\end{array}$ & $\begin{array}{l}\text { Inhibited } \\
\text { VEGFR2- } \\
\text { dependent } \\
\text { tumor growth. }\end{array}$ & 2272.15 Da. & $\begin{array}{l}\text { Secondary } \\
\text { structures are } \\
\text { absent. }\end{array}$ & $\begin{array}{c}\text { X-Ray } \\
\text { diffraction. }\end{array}$ & $\begin{array}{c}\text { FTIR method } \\
\text { b-sheet structure } \\
\text { change in b-structured } \\
\text { conformation. }\end{array}$ & ThT. & $\begin{array}{l}300 \mathrm{mM} \text { vascin in } 1 \% \\
(\mathrm{w} / \mathrm{v}) \mathrm{NH}_{4} \mathrm{CO}_{3} \text { after } \\
24 \mathrm{~h} \text { incubation at } \\
\text { room temperature. }\end{array}$ & [225] \\
\hline
\end{tabular}


Table 1. Cont.

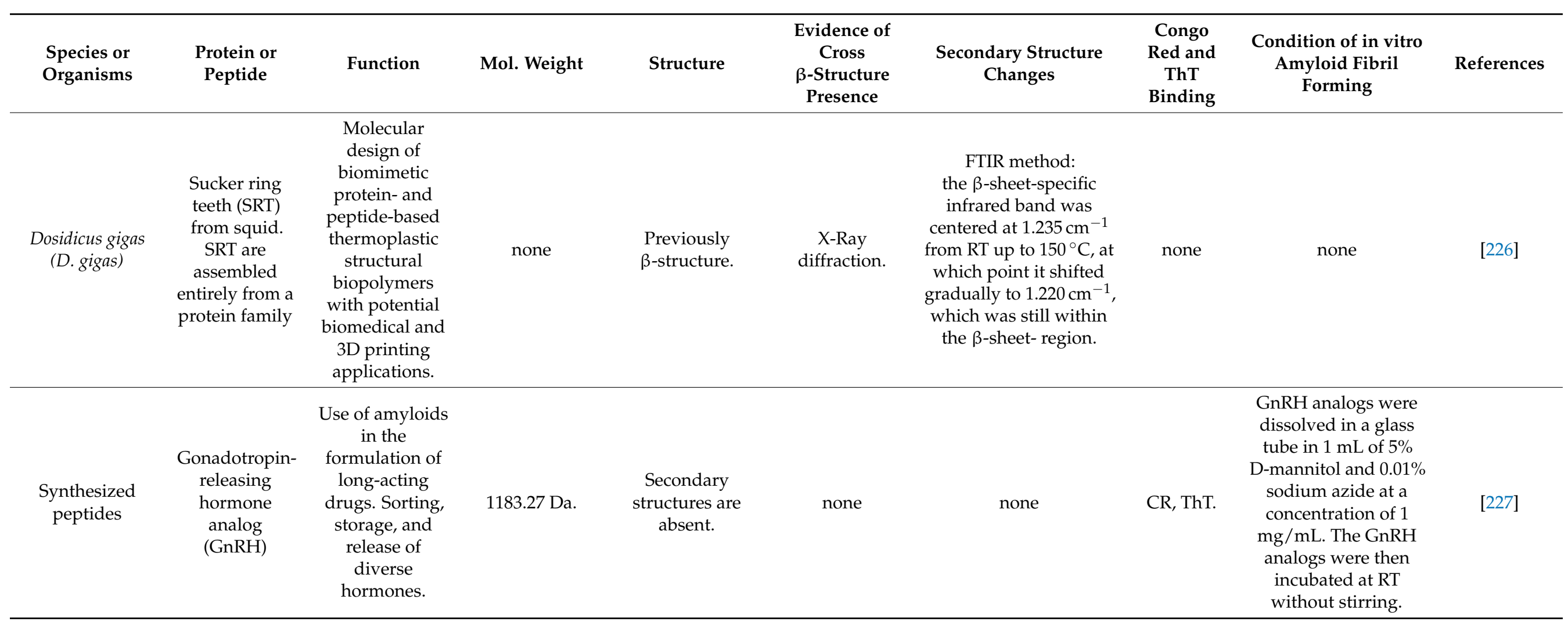


Table 1. Cont.

\begin{tabular}{|c|c|c|c|c|c|c|c|c|c|}
\hline $\begin{array}{l}\text { Species or } \\
\text { Organisms }\end{array}$ & $\begin{array}{l}\text { Protein or } \\
\text { Peptide }\end{array}$ & Function & Mol. Weight & Structure & $\begin{array}{l}\text { Evidence of } \\
\text { Cross } \\
\beta \text {-Structure } \\
\text { Presence }\end{array}$ & $\begin{array}{c}\text { Secondary Structure } \\
\text { Changes }\end{array}$ & $\begin{array}{l}\text { Congo } \\
\text { Red and } \\
\text { ThT } \\
\text { Binding }\end{array}$ & $\begin{array}{c}\text { Condition of in vitro } \\
\text { Amyloid Fibril } \\
\text { Forming }\end{array}$ & References \\
\hline
\end{tabular}


What is the reason for the non-toxicity properties of functional amyloids? Why can one be pathological but another functional? To date, the mechanisms behind the non-toxicity properties of functional amyloids are still unclear. However, Jackson and Hewitt suggested realistic ways to resolve this: (1) regulating the content of amyloidogenic peptides/proteins; (2) decreasing the time of the oligomers state during amyloidogenesis; (3) locating amyloids within membrane-bound organelles (e.g., melanosoma); and (4) regulating amyloid formation by other molecules and disassembling the fibrils under physiological conditions [229].

Might it be better to use the aggregation properties of amyloids? Scientists have now discovered how amyloid aggregates can inhibit VEGFR2-dependent tumor growth in a mouse tumor model [213], which was also observed using different human cell lines [226]. Oligomers can influence tumor growth too [230]. It has been shown that amyloids have antimicrobial properties $[163,231]$, and these properties can be realized to $\beta$-sheet ion channel formation by amyloids [232].

\section{Conclusions}

The discovery of amyloids in organs and tissues in various diseases has tarnished the reputation of these formations for many years. Until now, amyloids have been considered to be harmful pathogenic aggregates, affecting cell homeostasis and, ultimately, resulting in cell death. There are numerous data on the toxicity of amyloids (A $\beta$ amyloids in particular). Meanwhile, recent studies report that amyloids may have a beneficial role in cells and in organisms, and not just contribute to the development of amyloidosis, including AD. The results obtained in these experiments will enable many researchers to refocus their efforts on diligent study of the structural features and functional properties of amyloids. This will also yield important data to support selection of the most appropriate approaches for treatment of amyloidosis.

Author Contributions: E.I.Y. conceived and drafted the manuscript; S.A.S., L.G.B. and A.G.B. also wrote the part of the manuscript; and I.M.V. checked the manuscript. All authors have read and agreed to the published version of the manuscript.

Funding: This study was supported by the Russian Foundation for Basic Research (project №19-3490054).

Institutional Review Board Statement: Not applicable.

Informed Consent Statement: Not applicable.

Data Availability Statement: Not applicable.

Conflicts of Interest: The authors declare no conflict of interest.

$\begin{array}{ll}\text { Abbreviations } \\ \text { A } \beta \quad \beta \text {-amyloid protein } \\ \text { APP } & \text { amyloid precursor protein } \\ \text { AD } & \text { Alzheimer's disease } \\ \text { CD } & \text { circular dichroism } \\ \text { FTIR } & \text { Fourier-transform infrared spectroscopy } \\ \text { NO } & \text { nitric oxide } \\ \text { PrP } & \text { prion protein } \\ \text { RC } & \text { random coil } \\ \text { RT } & \text { room temperature }\end{array}$

\section{References}

1. Nizhnikov, A.A.; Antonets, K.S.; Inge-Vechtomov, S.G. Amyloids: From Pathogenesis to Function. Biochemistry 2015, 80, 1127-1144. [CrossRef] [PubMed]

2. Kyle, R. Amyloidosis: A Convoluted Story. Br. J. Haematol. 2001, 114, 529-538. [CrossRef]

3. Sipe, J.D.; Cohen, A.S. Review: History of Amyloid Fibril. J. Struct. Biol. 2000, 130, 88-89. [CrossRef] 
4. Westermark, P.; Benson, M.D.; Buxbaum, J.N.; Cohen, A.S.; Frangione, B.; Ikeda, S.I.; Masters, C.L.; Merlini, G.; Sipe, J.D.A.; Saraiva, M.J. Primer of Amyloid Nomenclature. Amyloid 2007, 14, 179-183. [CrossRef] [PubMed]

5. Horwich, A.L.; Weissman, J.S. Deadly Conformations-Protein Misfolding in Prion Disease. Cell 1997, 89, 499-510. [CrossRef]

6. Prusiner, S.B.; Scott, M.R.; DeArmond, S.J.; Cohen, F.E. Prion Protein Biology. Cell 1998, 93, 337-348. [CrossRef]

7. Kushnirov, V.V.; Vishnevskaya, A.B.; Alexandrov, I.M.; Michael, D. Ter-Avanesyan Prion and Nonprion. Amyloids 2007, 1, 179-184.

8. Antonets, K.S.; Belousov, M.V.; Sulatskaya, A.I.; Belousova, M.E.; Kosolapova, A.O.; Sulatsky, M.I.; Andreeva, E.A.; Zykin, P.A.; Malovichko, Y.V.; Shtark, O.Y.; et al. Accumulation of Storage Proteins in Plant Seeds is Mediated by Amyloid Formation. PLoS Biol. 2020, 18, e3000564. [CrossRef]

9. Surguchov, A.; Emamzadeh, F.N.; Surguchev, A.A. Amyloidosis and Longevity: A Lesson from Plants. Biology $2019,8,43$. [CrossRef]

10. Rçmling, U.; Bian, Z.; Hammar, M.; Sierralta, W.D.; Normark, S. Curli Fibers are Highly Conserved between Salmonella typhimurium and Escherichia coli with Respect to Open Structure and Regulation. J. Bacteriol. 1998, 180, 722-731. [CrossRef]

11. Claessen, D.; Rink, R.; de Jong, W.; Siebring, J.; de Vreughd, P.; Boersma, F.G.H.; Dijkhuizen, L.; Wçsten, H.A.B. A Novel Class of Secreted Hydrophobic Proteins is Involved in Aerial Hyphae Formation in Streptomyces coelicolor by Forming Amyloid-like Fibrils. Genes Dev. 2003, 17, 1714-1726. [CrossRef]

12. Otzen, D.; Nielsen, P.H. We Find Them Here, We Find Them There: Functional Bacterial Amyloid. Cell Mol Life Sci. 2008, 65, 910-927. [CrossRef]

13. Wöesten, H.A.B.; de Vocht, M.L. Hydrophobins, the Fungal Coat Unraveled. Biochim. Biophys. Acta 2000, 1469, 79-86. [CrossRef]

14. Iconomidou, V.A.; Chryssikos, G.D.; Gionis, V.; Galanis, A.S.; Cordopatis, P.; Hoenger, A.; Hamodrakas, S.J. Amyloid Fibril Formation Propensity is Inherent into the Hexapeptidetandemly Repeating Sequence of the Central Domain of Silk Moth Chorion Proteins of the A-family. J. Struct. Biol. 2006, 156, 480-488. [CrossRef]

15. Slotta, U.; Hess, S.; Spiess, K.; Stromer, T.; Serpell, L.; Scheibel, T. Spider Silk and Amyloid Fibrils: A Structural Comparison. Macromol. Biosci. 2007, 7, 183-188. [CrossRef]

16. Si, K.; Lindquist, S.; Kandel, E.R. A Neuronal Isoform of the Aplysia CPEB has Prion-like Properties. Cell 2003, $115,879-891$. [CrossRef]

17. Guyonnet, B.; Egge, N.; Cornwall, G.A. Functional Amyloids in the Mouse Sperm Acrosome. Mol. Cell Biol. 2014, 34, 2624-2634. [CrossRef] [PubMed]

18. Fowler, D.M.; Koulov, A.V.; Alory-Jost, C.; Marks, M.S.; Balch, W.E.; Kelly, J.W. Functional Amyloid Formation within Mammalian Tissue. PLoS Biol. 2006, 4, e6. [CrossRef]

19. Maji, S.K.; Perrin, M.H.; Sawaya, M.R.; Jessberger, S.; Vadodaria, K.; Rissman, R.A.; Singru, P.S.; Nilsson, K.P.; Simon, R.; Schubert, D.; et al. Functional Amyloids as Natural Storage of Peptide Hormones in Pituitary Secretory Granules. Science 2009, 325, 328-332. [CrossRef] [PubMed]

20. Hardy, J.A.; Higgins, G.A. Alzheimer's Disease: The Amyloid Cascade Hypothesis. Science 1992, 256, 184-185. [CrossRef] [PubMed]

21. Mann, D.M.A. Alzheimer's Disease and Down's Syndrome. Histopathology 1988, 13, 125-137. [CrossRef] [PubMed]

22. Shamas-Ud-Din, S.; Holmes, C. Genetics of Down's Syndrome and Alzheimer's Disease. Br. J. Psychiatry 2002, 181, 167-168. [CrossRef] [PubMed]

23. Chartier-Harlin, M.C.; Crawford, F.; Houlden, H.; Warren, A.; Hughes, D.; Fidani, L.; Goate, A.; Rossor, M.; Roques, P.; Hardy, J.; et al. Early-onset Alzheimer's Disease Caused by Mutations at Codon 717 of the f3-amyloid Precursor Protein Gene. Nature 1991, 353, 844-846. [CrossRef] [PubMed]

24. Cai, X.-D.; Golde, T.; Younkin, S. Release of Excess Amyloid Beta-protein from a Mutant Amyloid Beta-protein Precursor. Science 1993, 259, 514-516. [CrossRef] [PubMed]

25. Citron, M.; Oltersorf, T.; Haass, C.; McConlogue, L.; Hung, A.Y.; Seubert, P.; Vigo-Pelfrey, C.; Lieberburg, I.; Selkoe, D.J. Mutation of the Beta-amyloid Precursor Protein in Familial Alzheimer's Disease Increases Beta-protein Production. Nature 1992, 360, 672-674. [CrossRef]

26. Murrell, J.; Farlow, M.; Ghetti, B.; Benson, M.D. Amutation in the Amyloid Precursor Protein Associated with Hereditary Alzheimer's Disease. Science 1991, 254, 97-99. [CrossRef]

27. Goate, A.; Chartier-Harlin, M.-C.; Mullan, M.; Brown, J.; Crawford, F.; Fidani, L.; Giuffra, L.; Haynes, A.; Irving, N.; James, L.; et al. Segregation of a Missense Mutation in the Amyloid Precursor Protein Gene with Familial Alzheimer's Disease. Nature 1991, 349, 704-706. [CrossRef]

28. Vassar, R. BACE1: The Beta-secretase Enzyme in Alzheimer's Disease. J. Mol. Neurosci. 2004, 23, 105-114. [CrossRef]

29. Benilova, I.; Karran, E.; De Strooper, B. The Toxic A $\beta$ Oligomer and Alzheimer's Disease: An Emperor in Need of Clothes. Nat. Neurosci. 2012, 15, 349-357. [CrossRef]

30. Yankner, B.A.; Dawes, L.R.; Fisher, S.; Villa-Komaroff, L.; Oster-Granite, M.L.; Neve, R.L. Neurotoxicity of a Fragment of the Amyloid Precursor Associated with Alzheimer's Disease. Science 1989, 245, 417-420. [CrossRef]

31. Yankner, J.A.; Duffy, L.K.; Kirschner, D.A. Neurotrophic and Neurotoxic Effects of Amyloid $\beta$ Protein Reversal by Tachykinin Neuropeptides. Science 1990, 250, 279-282. [CrossRef]

32. Mattson, M.P.; Tomaselli, K.J.; Rydel, R.E. Calcium De-stabilizing and Neurodegenerative Effects of Aggregated $\beta$-amyloid are Attenuated by Basic FGF. Brain Res. 1993, 621, 35-49. [CrossRef] 
33. Barrow, C.J.; Zagorski, M.G. Solution Structures of $\beta$ Peptide and Its Constituent Fragments: Relation to Amyloid Deposition. Science 1991, 253, 179-182. [CrossRef]

34. Whitson, J.S.; Glabe, C.G.; Shitani, E.; Abcar, A.; Cotman, C.W. $\beta$-Amyloid Protein Promotes Neuritic Branching in Hippocampal Cultures. Neurosci. Lett. 1990, 110, 319-324. [CrossRef]

35. Burdick, D.; Soreghan, B.; Kosmoski, J.; Knauer, M.; Henschen, A.; Yates, J.; Cotman, C.; Glabe, C. Assembly and Aggregation Properties of Synthetic Alzheimer's A4/ $\beta$ Amyloid Peptide Analogs. J. Biol. Chem. 1992, 267, 546-554. [CrossRef]

36. Hilbich, C.; Kisters-Woike, B.; Reed, J.; Masters, C.L.; Beyreuther, K. Aggregation and Secondary Structure of Synthetic Amyloid flA4 Peptides of Alzheimer's Disease. J. Mol. Biol. 1991, 218, 149-163. [CrossRef]

37. Kaltschmidt, B.; Uherek, M.; Wellman, H.; Volk, B.; Kaltschmidt, C. Inhibition of NF-KB Potentates Amyloid $\beta$-mediatated Neuronal Apoptosis. Proc. Natl. Acad. Sci. USA 1999, 96, 9409-9414. [CrossRef]

38. Kuperstein, I.; Broersen, K.; Benilova, I.; Rozenski, J.; Jonckheere, W.; Debulpaep, M.; Vandersteen, A.; Segers-Nolten, I.; Van Der Werf, K.; Subramaniam, V.; et al. Neurotoxicity of Alzheimer's Disease A $\beta$ Peptides is Induced by Small Changes in the A $\beta 42$ to A $\beta 40$ Ratio. EMBO J. 2010, 29, 3408-3420. [CrossRef]

39. Gibson, G.E.; Peterson, C. Calcium and the Aging Nervous System. Neurobiol. Aging 1987, 8, 329-343. [CrossRef]

40. Mattson, M.P. Calcium as Sculptor and Destroyer of Neural Circuitry. Exp. Gerontol. 1992, 27, 29-49. [CrossRef]

41. Mattson, M.P. Antigenic Changes Similiar to Those Seen in Neurofibrillary Tangles are Elicited by Glutamate and Calcium Influx in Cultured Hippocampal Neurons. Neuron 1990, 4, 105-117. [CrossRef]

42. Mattson, M.P. Calcium and Neuronal Injury in Alzheimer's Disease. Contributions of Beta-amyloid Precursor Protein Mismetabolism, Free Radicals, and Metabolic Compromise. Ann. N. Y. Acad. Sci. 1994, 15, 50-76.

43. Weiss, J.H.; Pike, C.J.; Cotman, C.W. Ca2+ Channel Blockers Attenuate Beta-amyloid Peptide Toxicity to Cortical Neurons in Culture. J. Neurochem. 1994, 62, 372-375. [CrossRef]

44. Avdulov, N.A.; Chochina, S.V.; Igbavboa, U.; Warden, C.S.; Vassiliev, A.V.; Wood, W.G. Lipid Binding to Amyloid Beta-peptide Aggregates: Preferential Binding of Cholesterol as Compared with Phosphatidylcholine and Fatty Acids. J. Neurochem. 1997, 69, 1746-1752. [CrossRef]

45. Demuro, A.; Parker, I.; Stutzmann, G.E. Calcium Signaling and Amyloid Toxicity in Alzheimer Disease. J. Biol. Chem. 2010, 285, 12463-12468. [CrossRef]

46. Müller, W.E.; Koch, S.; Eckert, A.; Hartmann, H.; Scheuer, K. Beta-amyloid Peptide Decreases Membrane Fluidity. Brain Res. 1995, 674, 133-136. [CrossRef]

47. Mason, R.P.; Trumbore, M.W.; Pettegrew, J.W. Molecular Membrane Interactions of a Phospholipid Metabolite. Implications for Alzheimer's Disease Pathophysiology. Ann. N. Y. Acad. Sci. 1996, 777, 368-373. [CrossRef] [PubMed]

48. Green, J.D.; Kreplak, L.; Goldsbury, C.; Li Blatter, X.; Stolz, M.; Cooper, G.S.; Seelig, A.; Kistler, J.; Aebi, U. Atomic Force Microscopy Reveals Defects within Mica Supported Lipid Bilayers Induced by the Amyloidogenic Human Amylin Peptide. J. Mol. Biol. 2004, 342, 877-887. [CrossRef]

49. Kawahara, M.; Kuroda, Y.; Arispe, N.; Rojas, E. Alzheimer's Beta-amyloid, Human Islet Amylin, and Prion Protein Fragment Evoke Intracellular Free Calcium Elevations by a Common Mechanism in a Hypothalamic GnRH Neuronal Cell Line. J. Biol. Chem. 2000, 275, 14077-14083. [CrossRef]

50. Kayed, R.; Sokolov, Y.; Edmonds, B.; McIntire, T.M.; Milton, S.C.; Hall, J.E.; Glabe, C.G. Permeabilization of Lipid Bilayers is a Common Conformation-dependent Activity of Soluble Amyloid Oligomers in Protein Misfolding Diseases. J. Biol. Chem. 2004, 279, 46363-46366. [CrossRef]

51. Arispe, N.; Rojas, E.; Pollard, H.B. Alzheimer Disease Amyloid Beta Protein Forms Calcium Channels in Bilayer Membranes: Blockade by Tromethamine and Aluminum. Proc. Natl. Acad. Sci. USA 1993, 90, 567-571. [CrossRef]

52. Arispe, N. Architecture of the Alzheimer's A Beta P Ion Channel Pore. J. Membr. Biol. 2004, 197, 33-48. [CrossRef]

53. Lin, M.C.; Kagan, B.L. Electrophysiologic Properties of Channels Induced by Abeta25-35 in Planar Lipid Bilayers. Peptides 2002, 23, 1215-1228. [CrossRef]

54. Kawahara, M.; Arispe, N.; Kuroda, Y.; Rojas, E. Alzheimer's Disease Amyloid Beta-protein Forms Zn(2+)-sensitive, Cationselective Channels Across Excised Membrane Patches from Hypothalamic Neurons. Biophys. J. 1997, 73, 67-75. [CrossRef]

55. Hirakura, Y.; Lin, M.C.; Kagan, B.L. Alzheimer Amyloid Abeta1-42 Channels: Effects of Solvent, pH, and Congo Red. J. Neurosci. Res. 1999, 57, 458-466. [CrossRef]

56. Blanchard, B.J.; Chen, A.; Rozeboom, L.M.; Stafford, K.A.; Weigele, P.; Ingram, V.M. Efficient Reversal of Alzheimer's Disease Fibril Formation and Elimination of Neurotoxicity by a Small Molecule. Proc. Natl. Acad. Sci. USA 2004, 101, 14326-14332. [CrossRef] [PubMed]

57. Guo, Q.; Furukawa, K.; Sopher, B.L.; Pham, D.G.; Xie, J.; Robinson, N.; Martin, G.M.; Mattson, M.P. Alzheimer's PS-1 Mutation Perturbs Calcium Homeostasis and Sensitizes PC12 Cells to Death Induced by Amyloid Beta-peptide. Neuroreport 1996, 8, 379-383. [CrossRef] [PubMed]

58. Mattson, M.P.; Chan, S.L. Calcium Orchestrates Apoptosis. Nat. Cell. Biol. 2003, 5, 1041-1043. [CrossRef]

59. Ferrarelli, L.K. New Connections: Amyloid- $\beta$, Calcium, and the Synapse. Sci. Signal. 2017, 10, eaao3024. [PubMed]

60. Tong, B.C.; Wu, A.J.; Li, M.; Cheung, K.H. Calcium Signaling in Alzheimer's Disease \& Therapies. Biochim. Biophys. Acta Mol. Cell Res. 2018, 1865, 1745-1760. 
61. Angelova, P.R.; Abramov, A.Y. Alpha-synuclein and Beta-amyloid-Different Targets, Same Players: Calcium, Free Radicals and Mitochondria in the Mechanism of Neurodegeneration. Biochem. Biophys. Res. Commun. 2017, 483, 1110-1115. [CrossRef] [PubMed]

62. Cristóvão, J.S.; Morris, V.K.; Cardoso, I.; Leal, S.S.; Martínez, J.; Botelho, H.M.; Göbl, C.; David, R.; Kierdorf, K.; Alemi, M.; et al. The Neuronal S100B Protein is a Calcium-tuned Suppressor of Amyloid- $\beta$ Aggregation. Sci. Adv. 2018, 4, eaaq1702. [CrossRef]

63. Kawahara, M.; Negishi-Kato, M.; Sadakane, Y. Calcium Dyshomeostasis and Neurotoxicity of Alzheimer's Beta-amyloid Protein. Expert Rev. Neurother. 2009, 9, 681-693. [CrossRef]

64. Sushma; Mondal, A.C. Role of GPCR Signaling and Calcium Dysregulation in Alzheimer's Disease. Mol. Cell. Neurosci. 2019, 101, 103414. [CrossRef]

65. Esteras, N.; Abramov, A.Y. Mitochondrial Calcium Deregulation in the Mechanism of Beta-Amyloid and Tau Pathology. Cells 2020, 9, 2135. [CrossRef]

66. Behl, C.; Davis, J.; Cole, G.M.; Schubert, D. Vitamin E Protects Nerve Cells from Amyloid Beta Protein Toxicity. Biochem. Biophys. Res. Commun. 1992, 186, 944-950. [CrossRef]

67. Hensley, K.; Carney, J.M.; Mattson, M.P.; Aksenova, M.; Harris, M.; Wu, J.F.; Floyd, R.A.; Butterfield, D.A. A Model for Betaamyloid Aggregation and Neurotoxicity Based on Free Radical Generation by the Peptide: Relevance to Alzheimer Disease. Proc. Natl. Acad. Sci. USA 1994, 91, 3270-3274. [CrossRef] [PubMed]

68. Smith, M.A.; Richey Harris, P.L.; Sayre, L.M.; Beckman, J.S.; Perry, G. Widespread Peroxynitrite-mediated Damage in Alzheimer's Disease. J. Neurosci. 1997, 17, 2653-2657. [CrossRef]

69. Smith, M.A.; Perry, G.; Richey, P.L.; Sayre, L.M.; Anderson, V.E.; Beal, M.F.; Kowall, N. Oxidative Damage in Alzheimer's. Nature 1996, 382, 120-121. [CrossRef]

70. Goodwin, J.L.; Uemura, E.; Cunnick, J.E. Microglial Release of Nitric Oxide by the Synergistic Action of Beta-amyloid and IFN-gamma. Brain Res. 1995, 692, 207-214. [CrossRef]

71. Geng, X.; Yang, B.; Li, R.; Teng, T.; Ladu, M.J.; Sun, G.Y.; Greenlief, C.M.; Lee, J.C. Effects of Docosahexaenoic Acid and Its Peroxidation Product on Amyloid- $\beta$ Peptide-Stimulated Microglia. Mol Neurobiol. 2020, 57, 1085-1098. [CrossRef] [PubMed]

72. Pappolla, M.A.; Omar, R.A.; Kim, K.S.; Robakis, N.K. Immunohistochemical Evidence of Oxidative (Corrected) Stress in Alzheimer's Disease. Am. J. Pathol. 1992, 140, 621-628.

73. Pereira, C.F.; Santos, A.E.; Moreira, P.I.; Pereira, A.C.; Sousa, F.J.; Cardoso, S.M.; Cruz, M.T. Is Alzheimer's Disease an Inflammasomopathy? Ageing Res. Rev. 2019, 56, 100966. [CrossRef]

74. Cheignon, C.; Tomas, M.; Bonnefont-Rousselot, D.; Faller, P.; Hureau, C.; Collin, F. Oxidative Stress and the Amyloid Beta Peptide in Alzheimer's Disease. Redox. Biol. 2018, 14, 450-464. [CrossRef] [PubMed]

75. Behl, C.; Davis, J.B.; Lesley, R.; Schubert, D. Hydrogen Peroxide Mediates Amyloid Beta Protein Toxicity. Cell 1994, 77, 817-827. [CrossRef]

76. Kaltschmidt, B.; Uherek, M.; Volk, B.; Baeuerle, P.A.; Kaltschmidt, C. Transcription Factor NF-kappaB is Activated in Primary Neurons by Amyloid Beta Peptides and in Neurons Surrounding Early Plaques from Patients with Alzheimer Disease. Proc. Natl. Acad. Sci. USA 1997, 94, 2642-2647. [CrossRef]

77. Pentreath, V.W. Responses of Cultured Astrocytes, C6 Glioma and 1321NI Astrocytoma Cells to Amyloid $\beta$-Peptide Fragments. Nonlinearity Biol. Toxicol. Med. 2004, 2, 45-63. [CrossRef]

78. Cotman, C.W.; Anderson, A.J. A Potential Role for Apoptosis in Neurodegeneration and Alzheimer's Disease. Mol. Neurobiol. 1995, 10, 19-45. [CrossRef] [PubMed]

79. Reiss, A.B.; Arain, H.A.; Stecker, M.M.; Siegart, N.M.; Kasselman, L.J. Amyloid Toxicity in Alzheimer's Disease. Rev. Neurosci. 2018, 29, 613-627. [CrossRef] [PubMed]

80. Leong, Y.Q.; Ng, K.Y.; Chye, S.M.; Ling, A.P.K.; Koh, R.Y. Mechanisms of Action of Amyloid-beta and Its Precursor Protein in Neuronal Cell Death. Metab. Brain Dis. 2020, 35, 11-30. [CrossRef]

81. Dickson, D.W. Apoptotic Mechanisms in Alzheimer Neurofibrillary Degeneration: Cause or Effect? J. Clin. Investig. 2004, 114, 23-27. [CrossRef] [PubMed]

82. Stadelmann, C.; Bruck, W.; Bancher, C.; Jellinger, K.; Lassmann, H. Alzheimer Disease: DNA Fragmentation Indicates Increased Neuronal Vulnerability, but not Apoptosis. J. Neuropathol. Exp. Neurol. 1998, 57, 456-464. [CrossRef]

83. Gong, Y.; Chang, L.; Viola, K.L.; Lacor, P.N.; Lambert, M.P.; Finch, C.E.; Krafft, G.A.; Klein, W.L. Alzheimer's Disease-affected Brain: Presence of Oligomeric A Beta Ligands (ADDLs) Suggests a Molecular Basis for Reversible Memory Loss. Proc. Natl. Acad. Sci. USA 2003, 100, 10417-10422. [CrossRef]

84. Su, J.H.; Anderson, A.J.; Cummings, B.J.; Cotman, C.W. Immunohistochemical Evidence for Apoptosis in Alzheimer's Disease. Neuroreport. 1994, 5, 2529-2533. [CrossRef] [PubMed]

85. Smale, G.; Nichols, N.R.; Brady, D.R.; Finch, C.E.; Horton, W.E., Jr. Evidence for Apoptotic Cell Death in Alzheimer's Disease. Exp. Neurol. 1995, 133, 225-230. [CrossRef]

86. Anderson, A.J.; Su, J.H.; Cotman, C.W. DNA Damage and Apoptosis in Alzheimer's Disease: Colocalization with c-Jun Immunoreactivity, Relationship to Brain Area, and Effect of Postmortem Delay. J. Neurosci. 1996, 16, 1710-1719. [CrossRef]

87. Obulesu, M.; Lakshmi, M.J. Apoptosis in Alzheimer's Disease: An Understanding of the Physiology, Pathology and Therapeutic Avenues. Neurochem. Res. 2014, 39, 2301-2312. [CrossRef] 
88. Park, G.; Nhan, H.S.; Tyan, S.; Kawakatsu, Y.; Zhang, C.; Navarro, M.; Koo, E.H. Caspase Activation and Caspase-Mediated Cleavage of APP Is Associated with Amyloid $\beta$-Protein-Induced Synapse Loss in Alzheimer's Disease. Cell Reports 2020, 31, 107839. [CrossRef] [PubMed]

89. Bredesen, D.E.; John, V.; Galvan, V. Importance of the Caspase Cleavage Site in Amyloid- $\beta$ Protein Precursor. J. Alzheimers Dis. 2010, 22, 57-63. [CrossRef]

90. Rissman, R.A.; Poon, W.W.; Blurton-Jones, M.; Oddo, S.; Torp, R.; Vitek, M.P.; LaFerla, F.M.; Rohn, T.T.; Cotman, C.W. Caspasecleavage of Tau is an Early Event in Alzheimer Disease Tangle Pathology. J. Clin. Investig. 2004, 114, 121-130. [CrossRef]

91. Glabe, C. Intracellular Mechanisms of Amyloid Accumulation and Pathogenesis in Alzheimer's Disease. J. Mol. Neurosci. 2001, 17, 137-145. [CrossRef]

92. Oddo, S.; Caccamo, A.; Shepherd, J.D.; Murphy, M.P.; Golde, T.E.; Kayed, R.; Metherate, R.; Mattson, M.P.; Akbari, Y.; LaFerla, F.M. Triple-transgenic Model of Alzheimer's Disease with Plaques and Tangles: Intracellular Abeta and Synaptic Dysfunction. Neuron 2003, 39, 409-421. [CrossRef]

93. Lustbader, J.W.; Cirilli, M.; Lin, C.; Xu, H.W.; Takuma, K.; Wang, N.; Caspersen, C.; Chen, X.; Pollak, S.; Chaney, M.; et al. ABAD Directly Links Abeta to Mitochondrial Toxicity in Alzheimer's Disease. Science 2004, 304, 448-452.

94. Oda, T.; Wals, P.; Osterburg, H.H.; Johnson, S.A.; Pasinetti, G.M.; Morgan, T.E.; Rozovsky, I.; Stine, W.B.; Snyder, S.W.; Holzman, T.F.; et al. Clusterin (apoJ) Alters the Aggregation of Amyloid Beta-peptide (A beta 1-42) and Forms Slowly Sedimenting A Beta Complexes That Cause Oxidative Stress. Exp. Neurol. 1995, 136, 22-31. [CrossRef] [PubMed]

95. Lambert, M.P.; Barlow, A.K.; Chromy, B.A.; Edwards, C.; Freed, R.; Liosatos, M.; Morgan, T.E.; Rozovsky, I.; Trommer, B.; Viola, K.L.; et al. Diffusible, Nonfibrillar Ligands Derived from Abeta1-42 are Potent Central Nervous System Neurotoxins. Proc. Natl. Acad. Sci. USA 1998, 95, 6448-6453. [CrossRef]

96. Walsh, D.M.; Klyubin, I.; Fadeeva, J.V.; Cullen, W.K.; Anwyl, R.; Wolfe, M.S.; Rowan, M.J.; Selkoe, D.J. Naturally Secreted Oligomers of Amyloid Beta Protein Potently Inhibit Hippocampal Long-term Potentiation in vivo. Nature 2002, 416, 535-539. [CrossRef]

97. McLean, C.A.; Cherny, R.A.; Fraser, F.W.; Fuller, S.J.; Smith, M.J.; Beyreuther, K.; Bush, A.I.; Masters, C.L. Soluble Pool of Abeta Amyloid as a Determinant of Severity of Neurodegeneration in Alzheimer's Disease. Ann. Neurol. 1999, 46, 860-866. [CrossRef]

98. Mc Donald, J.M.; Savva, G.M.; Brayne, C.; Welzel, A.T.; Forster, G.; Shankar, G.M.; Selkoe, D.J.; Ince, P.G.; Walsh, D.M. Medical Research Council Cognitive Function and Ageing Study. The Presence of Sodium Dodecyl Sulphate-stable Abeta Dimers is Strongly Associated with Alzheimer-type Dementia. Brain 2010, 133, 1328-1341. [CrossRef] [PubMed]

99. De Strooper, B. Proteases and Proteolysis in Alzheimer Disease: A Multifactorial View on the Disease Process. Physiol. Rev. 2010, 90, 465-494. [CrossRef]

100. Nilsberth, C.; Westlind-Danielsson, A.; Eckman, C.B.; Condron, M.M.; Axelman, K.; Forsell, C.; Stenh, C.; Luthman, J.; Teplow, D.B.; Younkin, S.G.; et al. The 'Arctic' APP Mutation (E693G) Causes Alzheimer's Disease by Enhanced Abeta Protofibril Formation. Nat Neurosci. 2001, 4, 887-893. [CrossRef]

101. Tomiyama, T.; Nagata, T.; Shimada, H.; Teraoka, R.; Fukushima, A.; Kanemitsu, H.; Takuma, H.; Kuwano, R.; Imagawa, M.; Ataka, S.; et al. A New Amyloid Beta Variant Favoring Oligomerization in Alzheimer's-type Dementia. Ann. Neurol. 2008, 63, 377-387. [CrossRef]

102. Bitan, G.; Fradinger, E.A.; Spring, S.M.; Teplow, D.B. Neurotoxic Protein Oligomers-What You See is not Always What You Get. Amyloid 2005, 12, 88-95. [CrossRef] [PubMed]

103. Hepler, R.W.; Grimm, K.M.; Nahas, D.D.; Breese, R.; Dodson, E.C.; Acton, P.; Keller, P.M.; Yeager, M.; Wang, H.; Shughrue, P.; et al. Solution State Characterization of Amyloid Beta-derived Diffusible Ligands. Biochemistry 2006, 45, 15157-15167. [CrossRef]

104. Hartley, D.M.; Zhao, C.; Speier, A.C.; Woodard, G.A.; Li, S.; Li, Z.; Walz, T. Transglutaminase Induces Protofibril-like Amyloid Beta-protein Assemblies That are Protease-resistant and Inhibit Long-term Potentiation. J. Biol. Chem. 2008, 283, 16790-16800. [CrossRef]

105. Smith, D.P.; Smith, D.G.; Curtain, C.C.; Boas, J.F.; Pilbrow, J.R.; Ciccotosto, G.D.; Lau, T.L.; Tew, D.J.; Perez, K.; Wade, J.D.; et al. Copper-mediated Amyloid-beta Toxicity is Associated with an Intermolecular Histidine Bridge. J. Biol. Chem. 2006, 281, 15145-15154. [CrossRef] [PubMed]

106. Galeazzi, L.; Ronchi, P.; Franceschi, C.; Giunta, S. In vitro Peroxidase Oxidation Induces Stable Dimers of Beta-amyloid (1-42) through Dityrosine Bridge Formation. Amyloid 1999, 6, 7-13. [CrossRef]

107. Demuro, A.; Mina, E.; Kayed, R.; Milton, S.C.; Parker, I.; Glabe, C.G. Calcium Dysregulation and Membrane Disruption as a Ubiquitous Neurotoxic Mechanism of Soluble Amyloid Oligomers. J. Biol. Chem. 2005, 280, 17294-17300. [CrossRef] [PubMed]

108. Aleksis, R.; Oleskovs, F.; Jaudzems, K.; Pahnke, J.; Biverstål, H. Structural Studies of Amyloid- $\beta$ Peptides: Unlocking the Mechanism of Aggregation and the Associated Toxicity. Biochimie 2017, 140, 176-192. [CrossRef]

109. Karran, E.; Mercken, M.; Strooper, B. The Amyloid Cascade Hypothesis for Alzheimer's Disease: An Appraisal for the Development of Therapeutics. Nat. Rev. Drug. Discov. 2011, 10, 698-712. [CrossRef]

110. Rajasekhar, K.; Chakrabarti, M.; Govindaraju, T. Function and Toxicity of Amyloid Beta and Recent Therapeutic Interventions Targeting Amyloid Beta in Alzheimer's Disease. Chem. Commun. 2015, 51, 13434-13450. [CrossRef]

111. Kollmer, M.; Close, W.; Funk, L.; Rasmussen, J.; Bsoul, A.; Schierhorn, A.; Schmidt, M.; Sigurdson, C.J.; Jucker, M.; Fändrich, M. Cryo-EM Structure and Polymorphism of A $\beta$ Amyloid Fibrils Purified from Alzheimer's Brain Tissue. Nature Commun. 2019, 10, 4760. [CrossRef] 
112. Braak, H.; Braak, E. Neuropathological Stageing of Alzheimer-related Changes. Acta Neuropathol. 1991, 82, 239-259. [CrossRef]

113. Terry, R.D.; Masliah, E.; Salmon, D.P.; Butters, N.; DeTeresa, R.; Hill, R.; Hansen, L.A.; Katzman, R. Physical Basis of Cognitive Alterations in Alzheimer's Disease: Synapse Loss is the Major Correlate of Cognitive Impairment. Ann. Neurol. 1991, 30, 572-580. [CrossRef] [PubMed]

114. ClinicalsTrails.gov. Available online: https:/ clinicaltrials.gov/ct2/results?cond=Alzheimer+Disease\&term $=\& \mathrm{cntry}=\&$ state $=$ \&city $=\&$ dist $=($ accessed on 5 April 2021).

115. Hardy, J.; Mayer, J. The Amyloid Cascade Hypothesis Has Misled the Pharmaceutical Industry. Biochem. Soc Trans. 2011, 39, 920-923.

116. Kosenko, E.A.; Solomadin, I.N.; Tikhonova, L.A.; Reddy, V.P.; Aliev, G.; Kaminsky, Y.G. Pathogenesis of Alzheimer Disease: Role of Oxidative Stress, Amyloid- $\beta$ Peptides, Systemic Ammonia and Erythrocyte Energy Metabolism. CNS Neurol. Disord. Drug. Targets. 2014, 13, 112-119. [CrossRef]

117. Schmitt, F.A.; Davis, D.G.; Wekstein, D.R.; Smith, C.D.; Ashford, J.W.; Markesbery, W.R. "Preclinical" AD Revisited: Neuropathology of Cognitively Normal Older Adults. Neurology 2000, 55, 370-376. [CrossRef] [PubMed]

118. Jagust, W.J.; Mormino, E.C. Lifespan Brain Activity, $\beta$-amyloid, and Alzheimer's Disease. Trends Cogn. Sci. 2011, 15, 520-526. [CrossRef] [PubMed]

119. Hemming, M.L.; Selkoe, D.J. Amyloid Beta-protein is Degraded by Cellular Angiotensin-converting Enzyme (ACE) and Elevated by an ACE Inhibitor. J. Biol. Chem. 2005, 280, 37644-37650. [CrossRef] [PubMed]

120. Holmes, C.; Boche, D.; Wilkinson, D.; Yadegarfar, G.; Hopkins, V.; Bayer, A.; Jones, R.W.; Bullock, R.; Love, S.; Neal, J.W.; et al. Long-term Effects of Abeta42 Immunisation in Alzheimer's Disease: Follow-up of a Randomised, Placebo-controlled Phase I Trial. Lancet 2008, 372, 216-223. [CrossRef]

121. Kurkinen, M. The Amyloid Hypothesis is too Good to be True. Alzheimers Dement. Cogn. Neurol. 2017, 1, 1-9. [CrossRef]

122. Orgogozo, J.M.; Gilman, S.; Dartigues, J.F.; Laurent, B.; Puel, M.; Kirby, L.C.; Jouanny, P.; Dubois, B.; Eisner, L.; Flitman, S.; et al. Subacute Meningoencephalitis in a Subset of Patients with AD after Abeta42 Immunization. Neurology 2003, 61, 46-54. [CrossRef] [PubMed]

123. Nicoll, J.A.; Wilkinson, D.; Holmes, C.; Steart, P.; Markham, H.; Weller, R.O. Neuropathology of Human Alzheimer Disease after Immunization with Amyloid-beta Peptide: A Case Report. Nat. Med. 2003, 9, 448-452. [CrossRef]

124. Tabira, T. Immunization Therapy for Alzheimer Disease: A Comprehensive Review of Active Immunization Strategies. Tohoku J. Exp. Med. 2010, 220, 95-106. [CrossRef] [PubMed]

125. Blass, J.P. Immunologic Treatment of Alzheimer's Disease. New Engl. J. Med. 1999, 341, 1694-1695. [CrossRef] [PubMed]

126. Brewer, G.J.; Oelshlegel, F.J., Jr.; Moore, L.G.; Noble, N.A. In vivo Red Cell Glycolytic Control and DPG-ATP Levels. Ann. N. Y. Acad. Sci. 1974, 241, 513-523. [CrossRef]

127. Bruce, D.G.; Davis, W.A.; Casey, G.P.; Clarnette, R.M.; Brown, S.G.; Jacobs, I.G.; Almeida, O.P.; Davis, T.M. Severe Hypoglycaemia and Cognitive Impairment in Older Patients with Diabetes: The Fremantle Diabetes Study. Diabetologia 2009, 52, $1808-1815$. [CrossRef]

128. Klepper, J.; Voit, T. Facilitated Glucose Transporter Protein Type 1 (GLUT1) Deficiency Syndrome: Impaired Glucose Transport into Brain-A Review. Eur. J. Pediatr. 2002, 161, 295-304. [CrossRef]

129. Ronnback, L.; Hansson, E. On the Potential Role of Glutamate Transport in Mental Fatigue. J. Neuroinflammation 2004, 1, 22 [CrossRef]

130. Llansola, M.; Rodrigo, R.; Monfort, P.; Montoliu, C.; Kosenko, E.; Cauli, O.; Piedrafita, B.; Mlili, N.; Felipo, V. NMDA Receptors in Hyperammonemia and Hepatic Encephalopathy. Metab Brain Dis. 2007, 22, 321-335. [CrossRef]

131. Hoyer, S. Oxidative Metabolism Deficiencies in Brains of Patients with Alzheimer's Disease. Acta Neurol. Scand. Suppl. 1996, 165, 18-24. [CrossRef]

132. Hoyer, S.; Oesterreich, K.; Wagner, O. Glucose Metabolism as the Site of the Primary Abnormality in Early-onset Dementia of Alzheimer Type? J. Neurol. 1988, 235, 143-148. [CrossRef]

133. Aliev, G.; Palacios, H.H.; Walrafen, B.; Lipsitt, A.E.; Obrenovich, M.E.; Morales, L. Brain Mitochondria as a Primary Target in the Development of Treatment Strategies for Alzheimer Disease. Int. J. Biochem. Cell Biol. 2009, 41, 1989-2004. [CrossRef] [PubMed]

134. Aliev, G.; Li, Y.; Palacios, H.H.; Obrenovich, M.E. Oxidative Stress Induced Mitochondrial DNA Deletion as a Hallmark for the Drug Development in the Context of the Cerebrovascular Diseases. Rec. Pat. Cardiovasc. Drug Discov. 2011, 6, 222-241. [CrossRef] [PubMed]

135. Lee, H.G.; Casadesus, G.; Zhu, X.; Takeda, A.; Perry, G.; Smith, M.A. Challenging the Amyloid Cascade Hypothesis: Senile Plaques and Amyloid-beta as Protective Adaptations to Alzheimer Disease. Ann. N. Y. Acad. Sci. 2004, 1019, 1-4. [CrossRef] [PubMed]

136. Lee, H.G.; Zhu, X.; Castellani, R.J.; Nunomura, A.; Perry, G.; Smith, M.A. Amyloid-beta in Alzheimer Disease: The Null vs. the Alternate Hypotheses. J. Pharmacol. Exp. Ther. 2007, 321, 823-829. [CrossRef] [PubMed]

137. Atwood, C.S.; Robinson, S.R.; Smith, M.A. Amyloid-beta: Redox-metal Chelator and Antioxidant. J. Alzheimers Dis. 2002, 4, 203-214. [CrossRef]

138. Smith, M.A.; Casadesus, G.; Joseph, J.A.; Perry, G. Amyloid-beta and Tau Serve Antioxidant Functions in the Aging and Alzheimer Brain. Free Radic. Biol. Med. 2002, 33, 1194-1199. [CrossRef] 
139. Soscia, S.J.; Kirby, J.E.; Washicosky, K.J.; Tucker, S.M.; Ingelsson, M.; Hyman, B.; Burton, M.A.; Goldstein, L.E.; Duong, S.; Tanzi, R.E.; et al. The Alzheimer's Disease-associated Amyloid Beta-protein is an Antimicrobial Peptide. PLoS ONE 2010, 5, e9505. [CrossRef]

140. de la Torre, J.C. Impaired Cerebromicrovascular Perfusion. Summary of Evidence in Support of Its Causality in Alzheimer's Disease. Ann. N. Y. Acad. Sci. 2000, 924, 136-152. [CrossRef]

141. de la Torre, J.C.; Aliev, G. Inhibition of Vascular Nitric Oxide after Rat Chronic Brain Hypoperfusion: Spatial Memory and Immunocytochemical Changes. J. Cereb. Blood Flow Metab. 2005, 25, 663-672. [CrossRef]

142. Wen, Z.; Xie, J.; Guan, Z.; Sun, D.; Yao, W.; Chen, K.; Yan, Z.Y.; Mu, Q. A Study of Hemorheological Behaviour for Patients with Alzheimer's Disease at the Early Stages. Clin. Hemorheol. Microcirc. 2000, 22, 261-266. [PubMed]

143. Kaminsky, Y.; Poghosyan, A.; Tikhonova, L.; Palacios, H.H.; Kamal, M.A.; Kosenko, E.; Aliev, G. Glycolytic and Proteolytic Metabolism in Erythrocytes from Elderly and Demented Patients. Am. J. Neuroprotect. Neuroregener. 2012, 4, 73-77. [CrossRef]

144. Kaminsky, Y.G.; Reddy, V.P.; Ashraf, G.M.; Ahmad, A.; Benberin, V.V.; Kosenko, E.A.; Aliev, G. Age-related Defects in Erythrocyte 2,3-diphosphoglycerate Metabolism in Dementia. Aging Dis. 2013, 4, 244-255. [CrossRef] [PubMed]

145. Norberg, K.; Siesio, B.K. Oxidative Metabolism of the Cerebral Cortex of the Rat in Severe Insulin-induced Hypoglycaemia. J. Neurochem. 1976, 26, 345-352. [CrossRef]

146. Kinney, J.W.; Bemiller, S.M.; Murtishaw, A.S.; Leisgang, A.M.; Salazar, A.M.; Lamb, B.T. Inflammation as a Central Mechanism in Alzheimer's Disease. Alzheimers Dement. Transl. Res. Clin. Interv. 2018, 4, 575-590. [CrossRef] [PubMed]

147. Rogers, J.; Cooper, N.R.; Webster, S.; Schultz, J.; McGeer, P.L.; Styren, S.D.; Civin, W.H.; Brachova, L.; Bradt, B.; Ward, P. Complement Activation by Beta-amyloid in Alzheimer Disease. Proc. Natl. Acad. Sci. USA 1992, 89, 10016-10020. [CrossRef]

148. Chen, S.; Frederickson, R.C.; Brunden, K.R. Neuroglial-mediated Immunoinflammatory Responses in Alzheimer's Disease: Complement Activation and Therapeutic Approaches. Neurobiol. Aging 1996, 17, 781-787. [CrossRef]

149. Jiang, H.; Burdick, D.; Glabe, C.G.; Cotman, C.W.; Tenner, A.J. Beta-amyloid Activates Complement by Binding to a Specific Region of the Collagen-like Domain of the C1q A Chain. J. of Immunol. 1994, 152, 5050-5059.

150. Afagh, A.; Cummings, B.J.; Cribbs, D.H.; Cotman, C.W.; Tenner, A.J. Localization and Cell Association of C1q in Alzheimer's Disease Brain. Exp. Neurol. 1999, 6138, 22. [CrossRef]

151. Webster, S.; Bradt, B.; Rogers, J.; Cooper, N.R. Aggregation State-dependent Activation of the Classical Complement Pathway by the Amyloid $\beta$ Peptide (A $\beta)$. J. Neurochem. 1997, 69, 388-398. [CrossRef]

152. Webster, S.; Lue, L.F.; Brachova, L.; Tenner, A.; McGeer, P.L.; Walker, D.; Bradt, B.; Cooper, N.R.; Rogers, J. Molecular and Cellular Characterization of the Membrane Attack Complex, C5b-9, in Alzheimer's Disease. Neurobiol. Aging 1997, 18, 415-421. [CrossRef]

153. Veerhuis, R.; Van Breemen, M.J.; Hoozemans, J.M. Amyloid Beta Plaque-associated Proteins C1q and SAP Enhance the Abeta1-42 Peptide-induced Cytokine Secretion by Adult Human Microglia in vitro. Acta Neuropathol. 2003, 105, 135. [CrossRef] [PubMed]

154. Tacnet-Delorme, P.; Chevallier, S.; Arlaud, G.J. $\beta$-Amyloid Fibrils Activate the C1 Complex of Complement Under Physiological Conditions: Evidence for a Binding Site for A $\beta$ on the C1q Globular Regions. J. Immunol. 2001, 167, 6374. [CrossRef]

155. Bradt, B.M.; Kolb, W.P.; Cooper, N.R. Complement-dependent Proinflammatory Properties of the Alzheimer's Disease Betapeptide. J. Exp. Med. 1998, 188, 431. [CrossRef] [PubMed]

156. Strohmeyer, R.; Shen, Y.; Rogers, J. Detection of Complement Alternative Pathway mRNA and Proteins in the Alzheimer's Disease Brain. Mol. Brain Res. 2000, 81, 7. [CrossRef]

157. Watson, M.D.; Roher, A.E.; Kim, K.S.; Spiegel, K.; Emmerlin, M.R. Complement Interactions with Amyloid $\beta 1-42$ : A Nidus for Inflammation in AD Brains. Amyloid 1997, 4, 147-156. [CrossRef]

158. Eikelenboom, P.; Stam, F.C. Immunoglobulins and Complement Factors in Senile Plaques. An Immunoperoxidase Study. Acta Neuropathol. 1982, 57, 239. [CrossRef]

159. McGeer, P.L.; Akiyama, H.; Itagaki, S.; McGeer, E.G. Activation of the Classical Complement Pathway in Brain Tissue of Alzheimer Patients. Neurosci. Lett. 1989, 107, 341. [CrossRef]

160. Shen, Y.; Li, R.; McGeer, E.G.; McGeer, P.L. Neuronal Expression of mRNAs for Complement Proteins of the Classical Pathway in Alzheimer Brain. Brain Res. 1997, 769, 391. [CrossRef]

161. Landlinger, C.; Oberleitner, L.; Gruber, P.; Noiges, B.; Yatsyk, K.; Santic, R.; Mandler, M.; Staffler, G. Active Immunization against Complement Factor C5a: A New Therapeutic Approach for Alzheimer's Disease. J. Neuroinflammation 2015, 12, 150. [CrossRef]

162. Yakupova, E.I.; Bobyleva, L.G.; Vikhlyantsev, I.M.; Bobylev, A.G. Complement System Activation by Amyloid Aggregates of $\mathrm{A} \beta(1-40)$ and $A \beta(1-42)$ Peptides: Facts and Hypotheses. Biophysics 2020, 65, 18-21. [CrossRef]

163. Emery, D.C.; Shoemark, D.K.; Batstone, T.E.; Waterfall, C.M.; Coghill, J.A.; Cerajewska, T.L.; Davies, M.; West, N.X.; Allen, S.J. 16S rRNA Next Generation Sequencing Analysis Shows Bacteria in Alzheimer's Post-Mortem Brain. Front. Aging Neurosci. 2017, 9 , 195. [CrossRef]

164. Kumar, D.K.; Choi, S.H.; Washicosky, K.J.; Eimer, W.A.; Tucker, S.; Ghofrani, J.; Lefkowitz, A.; McColl, G.; Goldstein, L.E.; Tanzi, R.E.; et al. Amyloid- $\beta$ Peptide Protects against Microbial Infection in Mouse and Worm Models of Alzheimer's Disease. Sci. Transl. Med. 2016, 8, 340ra72. [CrossRef]

165. Daskalov, A.; Saupe, S.J. The Expanding Scope of Amyloid Signalling. Prion 2021, 15, 21-28. [CrossRef] [PubMed]

166. Nicastro, L.; Tükel, Ç. Bacterial Amyloids: The Link between Bacterial Infections and Autoimmunity. Trends Microbiol. 2019, 27, 954-963. [CrossRef] 
167. Olsen, A.; Jonsson, A.; Normark, S. Fibronectin Binding Mediated by a Novel Class of Surface Organelles on Escherichia coli. Nature 1976, 338, 652-655. [CrossRef] [PubMed]

168. Álvarez-Mena, A.; Cámara-Almirón, J.; de Vicente, A.; Romero, D. Multifunctional Amyloids in the Biology of Gram-Positive Bacteria. Microorganisms 2020, 8, 2020. [CrossRef] [PubMed]

169. Pham, C.L.; Kwan, A.H.; Sunde, M. Functional Amyloid: Widespread in Nature, Diverse in Purpose. Essays Biochem. 2014, 56, 207-219. [PubMed]

170. Balistreri, A.; Goetzler, E.; Chapman, M. Functional Amyloids Are the Rule Rather Than the Exception in Cellular Biology. Microorganisms 2020, 8, 1951. [CrossRef]

171. Pulze, L.; Bassani, B.; Gini, E.; D’Antona, P.; Grimaldi, A.; Luini, A.; Marino, F.; Noonan, D.M.; Tettamanti, G.; Valvassori, R.; et al. NET Amyloidogenic Backbone in Human Activated Neutrophils. Clin. Exp. Immunol. 2016, 183, 469-479. [CrossRef]

172. Vogler, T.O.; Wheeler, J.R.; Nguyen, E.D.; Hughes, M.P.; Britson, K.A.; Lester, E.; Rao, B.; Betta, N.D.; Whitney, O.N.; Ewachiw, T.E.; et al. TDP-43 and RNA Form Amyloid-like Myo-granules in Regenerating Muscle. Nature 2018, 563, 508-513. [CrossRef] [PubMed]

173. Nizhnikov, A.A.; Antonets, K.S.; Bondarev, S.A.; Inge-Vechtomov, S.G.; Derkatch, I.L. Prions, Amyloids, and RNA: Pieces of a Puzzle. Prion 2016, 10, 182-206. [CrossRef]

174. Bardin, T.; Daskalov, A.; Barrouilhet, S.; Granger-Farbos, A.; Salin, B.; Blancard, C.; Kauffmann, B.; Saupe, S.J.; Cousto, U.V. Partial Prion Cross-Seeding between Fungal and Mammalian Amyloid Signaling Motifs. mBio 2021, 12, e02782-20. [CrossRef] [PubMed]

175. Kosolapova, A.O.; Antonets, K.S.; Belousov, M.V.; Nizhnikov, A.A. Biological Functions of Prokaryotic Amyloids in Interspecies Interactions: Facts and Assumptions. Int. J. Mol. Sci. 2020, 21, 7240. [CrossRef]

176. Chapman, M.R.; Robinson, L.S.; Pinkner, J.S.; Roth, R.; Heuser, J.; Hammar, M.; Normark, S.; Hultgren, S.J. Role of Escherichia coli Curli Operons in Directing Amyloid Fiber Formation. Science 2002, 295, 851-855. [CrossRef] [PubMed]

177. Mackay, J.P.; Matthews, J.M.; Winefield, R.D.; Mackay, L.G.; Haverkamp, R.G.; Templeton, M.D. The Hydrophobin EAS is Largely Unstructured in Solution and Functions by Forming Amyloid-like Structures. Structure 2001, 9, 83-91. [CrossRef]

178. Kenney, J.M.; Knight, D.; Wise, M.J.; Vollrath, F. Amyloidogenic Nature of Spider Silk. Eur. J. Biochem. 2002, $269,4159-4163$. [CrossRef]

179. Berson, J.F.; Theos, A.C.; Harper, D.C.; Tenza, D.; Raposo, G.; Marks, M.S. Proprotein Convertase Cleavage Liberates a Fibrillogenic Fragment of a Resident Glycoprotein to Initiate Melanosome Biogenesis. J. Cell Biol. 2003, 161, 521-533. [CrossRef]

180. Chien, P.; Weissman, J.S.; DePace, A.H. Emerging Principles of Conformation-based Prion Inheritance. Annu. Rev. Biochem. 2004, 73, 617-656. [CrossRef] [PubMed]

181. Eaglestone, S.S.; Cox, B.S.; Tuite, M.F. Translation Termination Efficiency Can be Regulated in Saccharomyces cerevisiae by Environmental Stress through a Prion-mediated Mechanism. EMBO J. 1999, 18, 1974-1981. [CrossRef]

182. Giaever, G.; Chu, A.M.; Ni, L.; Connelly, C.; Riles, L.; Véronneau, S.; Dow, S.; Lucau-Danila, A.; Anderson, K.; André, B.; et al. Functional Profiling of the Saccharomyces cerevisiae Genome. Nature 2002, 418, 387-391. [CrossRef]

183. Nakayashiki, T.; Kurtzman, C.P.; Edskes, H.K.; Wickner, R.B. Yeast Prions [URE3] and [PSI+] are Diseases. Proc. Natl. Acad. Sci. USA 2005, 102, 10575-10580. [CrossRef]

184. Coustou, V.; Deleu, C.; Saupe, S.; Begueret, J. The Protein Product of the Het-s Heterokaryon Incompatibility Gene of the Fungus Podospora anserina Behaves as a Prion Analog. Proc. Natl. Acad. Sci. USA 1997, 94, 9773-9778. [CrossRef]

185. Saupe, S.J. Molecular Genetics of Heterokaryon Incompatibility in Filamentous Ascomycetes. Microbiol. Mol. Biol. Rev. 2000, 64, 489-502. [CrossRef] [PubMed]

186. Dueholm, M.S.; Petersen, S.V.; Sonderkaer, M.; Larsen, P.; Christiansen, G.; Hein, K.L.; Enghild, J.J.; Nielsen, J.L.; Nielsen, K.L.; Nielsen, P.H.; et al. Functional Amyloid in Pseudomonas. Mol. Microbiol. 2010, 77, 1009-1020. [CrossRef] [PubMed]

187. Otzen, D. Functional Amyloid: Turning Swords into Plowshares. Prion 2010, 4, 256-264. [CrossRef]

188. Shewmaker, F.; McGlinchey, R.P.; Wickner, R.B. Structural Insights into Functional and Pathological Amyloid. J. Biol. Chem. 2011, 286, 16533-16540. [CrossRef]

189. Schwartz, K.; Boles, B.R. Microbial Amyloids: Functions and Interactions within the Host. Curr. Opin. Microbiol. 2013, 16, 93-99. [CrossRef] [PubMed]

190. Adda, C.G.; Murphy, V.J.; Sunde, M.; Waddington, L.J.; Schloegel, J.; Talbo, G.H.; Vingas, K.; Kienzle, V.; Masciantonio, R.; Howlett, G.J.; et al. Plasmodium Falciparum Merozoite Surface Protein 2 is Unstructured and Forms Amyloid-like Fibrils. Mol. Biochem. Parasitol. 2009, 166, 159-171. [CrossRef]

191. Berthelot, K.; Lecomte, S.; Estevez, Y.; Coulary-Salin, B.; Bentaleb, A.; Cullin, C.; Deffieux, A.; Peruch, F. Rubber Elongation Factor (REF), a Major Allergen Component in Hevea brasiliensis latex Has Amyloid Properties. PLoS ONE 2012, 7, e48065. [CrossRef]

192. Gossler-Schofberger, R.; Hesser, G.; Reif, M.M.; Friedmann, J.; Duscher, B.; Toca-Herrera, J.L.; Oostenbrink, C.; Jilek, A. A Stereochemical Switch in the aDrs Model System, a Candidate for a Functional Amyloid. Arch. Biochem. Biophys. 2012, 522, 100-106. [CrossRef]

193. Li, J.; McQuade, T.; Siemer, A.B.; Napetschnig, J.; Moriwaki, K.; Hsiao, Y.S.; Damko, E.; Moquin, D.; Walz, T.; McDermott, A.; et al. The RIP1/RIP3 Necrosome Forms a Functional Amyloid Signaling Complex Required for Programmed Necrosis. Cell 2012, 150, 339-350. [CrossRef] [PubMed]

194. Barnhart, M.M.; Chapman, M.R. Curli Biogenesis and Function. Annu. Rev. Microbiol. 2006, 60, 131-147. [CrossRef] [PubMed] 
195. Cherny, I.; Rockah, L.; Levy-Nissenbaum, O.; Gophna, U.; Ron, E.Z.; Gazit, E. The Formation of Escherichia coli Curli Amyloid Fibrils is Mediated by Prion-like Peptide Repeats. J. Mol. Biol. 2005, 352, 245-252. [CrossRef]

196. Shewmaker, F.; McGlinchey, R.P.; Thurber, K.R.; McPhie, P.; Dyda, F.; Tycko, R.; Wickner, R.B. The Functional Curli Amyloid is not Based on In-register Parallel Beta-sheet Structure. J. Biol. Chem. 2009, 284, 25065-25076. [CrossRef]

197. Sawyer, E.B.; Claessen, D.; Haas, M.; Hurgobin, B.; Gras, S.L. The Assembly of Individual Chaplin Peptides from Streptomyces coelicolor into Functional Amyloid Fibrils. PLoS ONE 2011, 6, e18839. [CrossRef]

198. Kosolapova, A.O.; Belousov, M.V.; Sulatskaya, A.I.; Belousova, M.E.; Sulatsky, M.I.; Antonets, K.S.; Volkov, K.V.; Lykholay, A.N.; Shtark, O.Y.; Vasileva, E.N.; et al. Two Novel Amyloid Proteins, RopA and RopB, from the Root Nodule Bacterium Rhizobium leguminosarum. Biomolecules 2019, 9, 694. [CrossRef]

199. Bieler, S.; Estrada, L.; Lagos, R.; Baeza, M.; Castilla, J.; Soto, C. Amyloid Formation Modulates the Biological Activity of a Bacterial Protein. J. Biol. Chem. 2005, 280, 26880-26885. [CrossRef]

200. Shahnawaz, M.; Park, K.W.; Mukherjee, A.; Diaz-Espinoza, R.; Soto, C. Prion-like Characteristics of the Bacterial Protein Microcin E492. Sci. Rep. 2017, 7, 45720. [CrossRef] [PubMed]

201. Arranz, R.; Mercado, G.; Martín-Benito, J.; Giraldo, R.; Monasterio, O.; Lagos, R.; Valpuesta, J.M. Structural Characterization of Microcin E492 Amyloid Formation: Identification of the Precursors. J. Struct. Biol. 2012, 178, 54-60. [CrossRef] [PubMed]

202. Oh, J.; Kim, J.G.; Jeon, E.; Yoo, C.H.; Moon, J.S.; Rhee, S.; Hwang, I. Amyloidogenesis of Type III-dependent Harpins from Plant Pathogenic Bacteria. J. Biol. Chem. 2007, 282, 13601-13609. [CrossRef] [PubMed]

203. Dos Reis, S.; Coulary-Salin, B.; Forge, V.; Lascu, I.; Bégueret, J.; Saupe, S.J. The HET-s Prion Protein of the Filamentous Fungus Podospora Anserina Aggregates in vitro into Amyloid-like Fibrils. J. Biol. Chem. 2002, 277, 5703-5706. [CrossRef]

204. Balguerie, A.; Dos Reis, S.; Ritter, C.; Chaignepain, S.; Coulary-Salin, B.; Forge, V.; Bathany, K.; Lascu, I.; Schmitter, J.M.; Riek, R.; et al. Domain Organization and Structure-function Relationship of the HET-s Prion Protein of Podospora Anserina. EMBO J. 2003, 22, 2071-2081. [CrossRef]

205. Ritter, C.; Maddelein, M.L.; Siemer, A.B.; Lührs, T.; Ernst, M.; Meier, B.H.; Saupe, S.J.; Riek, R. Correlation of Structural Elements and Infectivity of the HET-s Prion. Nature 2005, 435, 844-848. [CrossRef]

206. Wan, W.; Wille, H.; Stöhr, J.; Baxa, U.; Prusiner, S.B.; Stubbs, G. Degradation of Fungal Prion HET-s(218-289) Induces Formation of a Generic Amyloid Fold. Biophys. J. 2012, 102, 2339-2344. [CrossRef]

207. Baxa, U.; Cheng, N.; Winkler, D.C.; Chiu, T.K.; Davies, D.R.; Sharma, D.; Inouye, H.; Kirschner, D.A.; Wickner, R.B.; Steven, A.C. Filaments of the Ure2p Prion Protein Have a Cross- $\beta$ Core Structure. J. Struct. Biol. 2005, 150, 170-179. [CrossRef]

208. Sant'Anna, R.; Fernández, M.; Batlle, C.; Navarro, S.; De Groot, N.S.; Serpell, L.; Ventura, S. Characterization of Amyloid Cores in Prion Domains. Sci. Rep. 2016, 6, 34274. [CrossRef] [PubMed]

209. King, C.Y.; Tittmann, P.; Gross, H.; Gebert, R.; Aebi, M.; Wüthrich, K. Prion-inducing Domain 2-114 of Yeast Sup35 Protein Transforms in vitro into Amyloid-like Filaments. Proc. Natl. Acad. Sci. USA 1997, 94, 6618-6622. [CrossRef] [PubMed]

210. True, H.L.; Berlin, I.; Lindquist, S.L. Epigenetic Regulation of Translation Reveals Hidden Genetic Variation to Produce Complex Traits. Nature 2004, 431, 184-187. [CrossRef]

211. Du, Z.; Park, K.W.; Yu, H.; Fan, Q.; Li, L. Newly Identified Prion Linked to the Chromatin-remodeling Factor Swi1 in Saccharomyces cerevisiae. Nat. Genet. 2008, 40, 460-465. [CrossRef]

212. Alberti, S.; Halfmann, R.; King, O.; Kapila, A.; Lindquist, S. A Systematic Survey Identifies Prions and Illuminates Sequence Features of Prionogenic Proteins. Cell 2009, 137, 146-158. [CrossRef]

213. Butko, P.; Buford, J.P.; Goodwin, J.S.; Stroud, P.A.; McCormick, C.L.; Cannon, G.C. Spectroscopic Evidence for Amyloid-like Interfacial Self-assembly of Hydrophobin Sc3. Biochem. Biophys. Res. Commun. 2001, 280, 212-215. [CrossRef] [PubMed]

214. de Vocht, M.L.; Reviakine, I.; Wösten, H.A.; Brisson, A.; Wessels, J.G.; Robillard, G.T. Structural and Functional Role of the Disulfide Bridges in the Hydrophobin SC3. J. Biol. Chem. 2000, 275, 28428-28432. [CrossRef] [PubMed]

215. Kwan, A.H.; Winefield, R.D.; Sunde, M.; Matthews, J.M.; Haverkamp, R.G.; Templeton, M.D.; Mackay, J.P. Structural Basis for Rodlet Assembly in Fungal Hydrophobins. Proc. Natl. Acad. Sci. USA 2006, 103, 3621-3626. [CrossRef] [PubMed]

216. Iconomidou, V.A.; Vriend, G.; Hamodrakas, S.J. Amyloids Protect the Silkmoth Oocyte and Embryo. FEBS Lett. 2000, 479, 141-145. [CrossRef]

217. Podrabsky, J.E.; Carpenter, J.F.; Hand, S.C. Survival of Water Stress in Annual Fish Embryos: Dehydration Avoidance and Egg Envelope Amyloid Fibers. Am. J. Physiol. Regul. Integr. Comp. Physiol. 2001, 280, R123-R131. [CrossRef]

218. Iconomidou, V.A.; Chryssikos, G.D.; Gionis, V.; Vriend, G.; Hoenger, A.; Hamodrakas, S.J. Amyloid-like Fibrils from an 18-residue Peptide Analogue of a Part of the Central Domain of the B-family of Silkmoth Chorion Proteins. FEBS Lett. 2001, 499, 268-273. [CrossRef]

219. Hamodrakas, S.J.; Jones, C.W.; Kafatos, F.C. Secondary Structure Predictions for Silkmoth Chorion Proteins. Biochim. Biophys. Acta Protein Struct. Mol. Enzymol. 1982, 700, 42-51. [CrossRef]

220. Dicko, C.; Knight, D.; Kenney, J.M.; Vollrath, F. Structural Conformation of Spidroin in Solution: A Synchrotron Radiation Circular Dichroism Study. Biomacromolecules 2004, 5, 758-767. [CrossRef]

221. Watt, B.; van Niel, G.; Fowler, D.M.; Hurbain, I.; Luk, K.C.; Stayrook, S.E.; Lemmon, M.A.; Raposo, G.; Shorter, J.; Kelly, J.W.; et al. N-terminal Domains Elicit Formation of Functional Pmel17 Amyloid Fibrils. J. Biol. Chem. 2009, 284, 35543-35555. [CrossRef] 
222. Si, K.; Giustetto, M.; Etkin, A.; Hsu, R.; Janisiewicz, A.M.; Miniaci, M.C.; Kim, J.H.; Zhu, H.; Kandel, E.R. A Neuronal Isoform of CPEB Regulates Local Protein Synthesis and Stabilizes Synapse-specific Long-term Facilitation in Aplysia. Cell 2003, 115, 893-904. [CrossRef]

223. Hervas, R.; Rau, M.J.; Park, Y.; Zhang, W.; Murzin, A.G.; Fitzpatrick, J.A.J.; Scheres, S.H.W.; Si, K. Cryo-EM Structure of a Neuronal Functional Amyloid Implicated in Memory Persistence in Drosophila. Science 2020, 367, 1230-1234. [CrossRef]

224. Ulamec, S.M.; Radford, S.E. Spot the Difference: Function vs. Toxicity in Amyloid Fibrils. Trends Biochem. Sci. 2020, 45, 635-636. [CrossRef] [PubMed]

225. Cervantes, S.; Bajakian, T.; Soria, M.; Falk, A.S.; Service, R.J.; Langen, R.; Siemer, A.B. Identification and Structural Characterization of the N-terminal Amyloid Core of Orb2 isoform A. Sci. Rep. 2016, 6, 38265. [CrossRef]

226. Gallardo, R.; Ramakers, M.; De Smet, F.; Claes, F.; Khodaparast, L.; Khodaparast, L.; Couceiro, J.R.; Langenberg, T.; Siemons, M.; Nyström, S.; et al. De novo Design of a Biologically Active Amyloid. Science 2016, 354, aah4949. [CrossRef] [PubMed]

227. Latza, V.; Guerette, P.; Ding, D.; Amini, S.; Kumar, A.; Schmidt, I.; Keating, S.; Oxman, N.; Weaver, J.C.; Masic, A. Multi-scale Thermal Stability of a Hard Thermoplastic Protein-based Material. Nat. Commun. 2015, 6, 8313. [CrossRef]

228. Maji, S.K.; Schubert, D.; Rivier, C.; Lee, S.; Rivier, J.E.; Riek, R. Amyloid as a Depot for the Formulation of Long-acting Drugs. PLoS Biol. 2008, 6, e17. [CrossRef]

229. Cui, M.; Qi, Q.; Gurry, T.; Zhao, T.; An, B.; Pu, J.; Gui, X.; Cheng, A.A.; Zhang, S.; Xun, D.; et al. Modular Genetic Design of Multi-domain Functional Amyloids: Insights into Self-assembly and Functional Properties. Chem. Sci. 2019, 10, 4004-4014. [CrossRef]

230. Jackson, M.P.; Hewitt, E.W. Why are Functional Amyloids Non-Toxic in Humans? Biomolecules 2017, 7, 71. [CrossRef] [PubMed]

231. Pavliukeviciene, B.; Zentelyte, A.; Jankunec, M.; Valiuliene, G.; Talaikis, M.; Navakauskiene, R.; Niaura, G.; Valincius, G. Amyloid $\beta$ Oligomers Inhibit Growth of Human Cancer Cells. PLoS ONE 2019, 14, e0221563. [CrossRef] [PubMed]

232. Kagan, B.L.; Jang, H.; Capone, R.; Teran Arce, F.; Ramachandran, S.; Lal, R.; Nussinov, R. Antimicrobial Properties of Amyloid Peptides. Mol Pharm. 2012, 9, 708-717. [CrossRef] [PubMed] 